\title{
Thermal and Photochemical Switching of Chiral Sugar Azoalkenes. A Mechanistic Interrogation
}

\author{
Ana María Sánchez-León, *[a] Pedro Cintas, ${ }^{[a]}$ Mark E. Light, ${ }^{[b]}$ and Juan Carlos Palacios*[a]
}

Dedicated to the memory of María Dolores Méndez
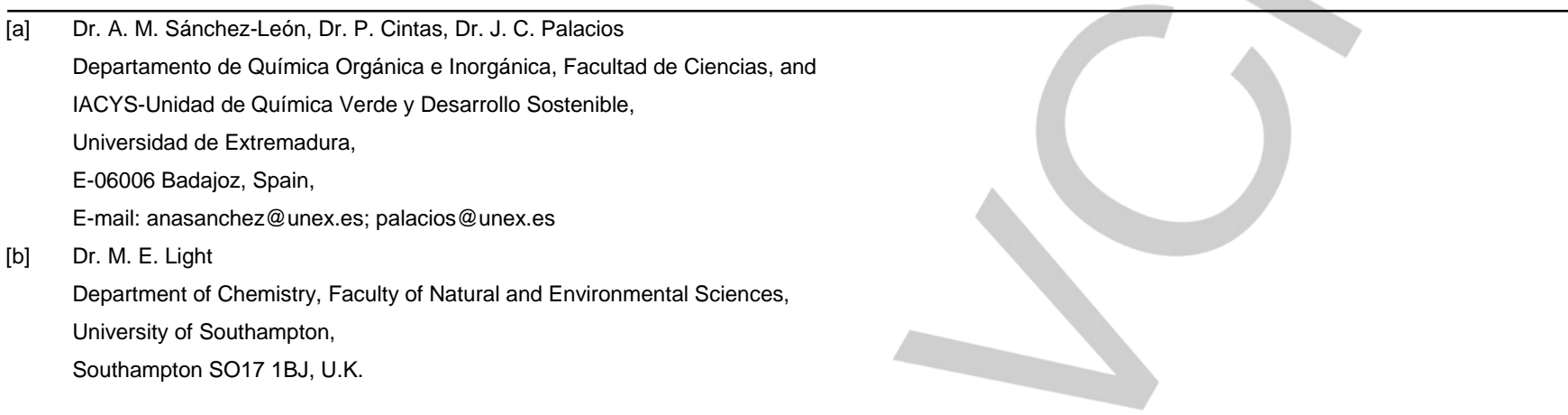

Supporting information and the ORCID identification number(s) for the author(s) of this article can be found via a link at the end of the document

\begin{abstract}
This manuscript describes a thorough study on the thermal and photochemical evolution of carbohydrate-based azoalkenes, which have been proposed as putative intermediates en route to other heterocyclic derivatives and nucleoside analogs. These substances represent new protagonists in the azo chemical space, under intense study due to reversible photoswitching of this functional group suitable for designing artificial nanomachines and responsive materials. Although structurally simple azadienes derived from monosaccharides have long been known, the dynamics of such species in solution and solid phase remains poorly characterized. Here, we show that such azoalkenes undergo $3 E \rightarrow 3 Z$ thermal isomerization, which is accelerated by the presence of Brönsted acids. On the other hand, they undergo $1 E \rightarrow 1 Z$ isomerization when irradiated by sunlight, while the reverse $1 Z \rightarrow 1 E$ isomerization occurs thermally in the dark or under acid catalysis. As a result, sugar monoazadienes not only exhibit inherent chirality, but also dual onoff isomerization under external stimuli. Both experiments and DFTbased computational analyses provide a consistent and unifying mechanistic picture of these transformations.
\end{abstract}

\section{Introduction}

The azo functional group has been a versatile structural motif in synthetic chemistry, whose importance dates back to the late 19th century, ranging from the preparation of the first azo-dyes to the seminal discovery of aromatic azo compounds as in-vivo prodrugs of sulfa drugs. The facile cis-trans isomerization of the azo group, usually achieved upon photoirradiation, thereby leading to salient luminescent changes, has attracted considerable attention in recent years. Substituted azobenzenes can thus work as photoswitches that can further be harnessed as artificial molecular machines, ${ }^{[1]}$ photoresponsive materials, ${ }^{[2]}$ as well as (bio)sensors and actuators. ${ }^{[3]}$ Moreover, the photoswitchable double bonds can be incorporated into active catalysts, ${ }^{[4]}$ and the azo group has shown a directing effect in organocatalysis. ${ }^{[5]}$ In addition, the term azolog space has been introduced to denote azologation of chemical groups (i.e. azoisosteres) for optical control of biological targets. ${ }^{[6]}$

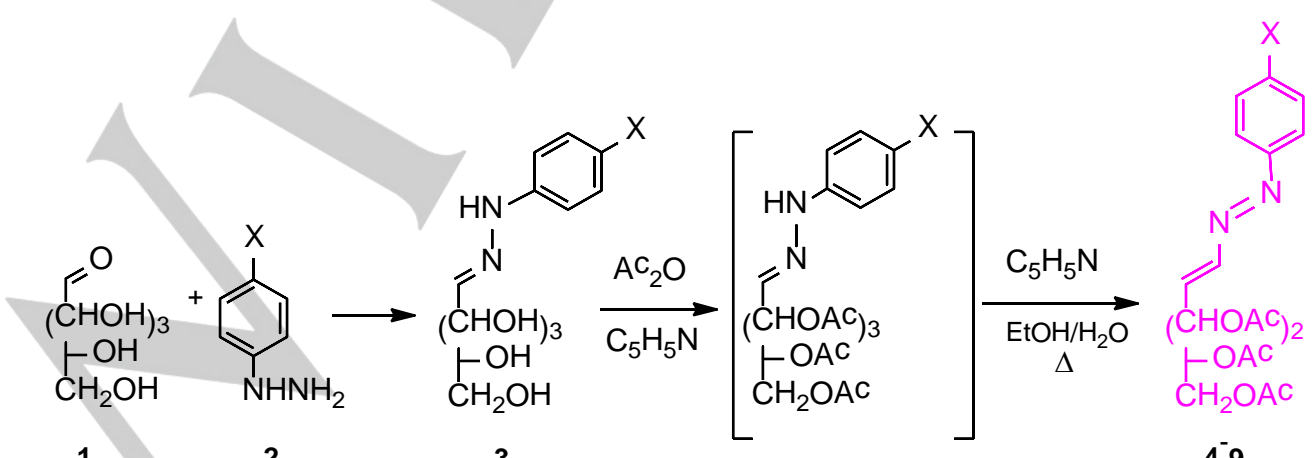




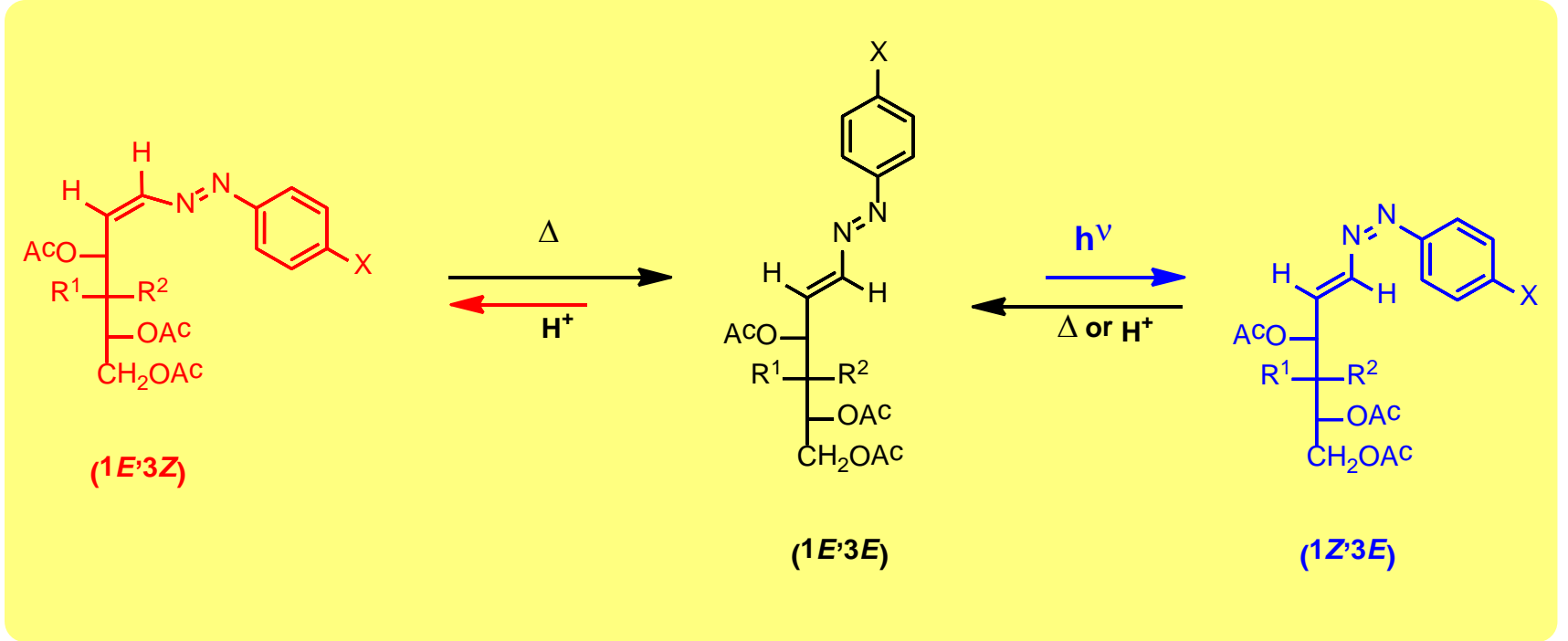

Scheme 2. Thermal and photochemical behavior of sugar 1,2-diaza-1,3-butadienes

The putative existence of sugar azoalkenes (sugar 1,2-diaza1,3-butadienes) should be traced back to pioneering studies by Wolfrom and associates during the acetylation of sugar hydrazones, ${ }^{[7,8]}$ although they proved to be elusive intermediates for several decades, and either postulated as transient intermediates or occasionally isolated in diverse reactions of unsaturated carbohydrates. ${ }^{[9]}$ A convenient two-step synthetic procedure involves the condensation of unprotected monosaccharides and aryl hydrazines followed by $\mathrm{O}$-acetylation and mild heating, thereby promoting elimination from a nonisolable monoazo-alkene to the corresponding diazo-diene (Scheme 1). ${ }^{[10]}$ Within the usual pattern of azoderivatives susceptible of photoactivation, these monosaccharidic azadienes (4-9) can be regarded as modified azobenzenes, ${ }^{[11]}$ lacking a second aromatic ring. This arrangement is unusual as most carbohydrate-containing azo-photoswitches incorporate the common azobenzene unit into the framework. ${ }^{[12]}$ The preparation of azobenzene-based glycoamphiphiles opens the door to novel materials that resemble glycolipids. ${ }^{[13]}$

Here, we look back at monosaccharidic 1,2-diaza-1,3butadienes, describing structural and configurational aspects in detail and focusing on their unexplored photophysical properties. The $O$-acylated sugar chain imparts chirality but also conformational flexibility, accompanied by enhanced hydrophobicity. It is well established that reversible trans-to-cis photoisomerization of the azobenzene motif can be tuned by shifts at shorter and longer wavelengths, respectively (the latter induced by thermal relaxation too). We show the dual lability of the $\mathrm{C}=\mathrm{C}$ and $\mathrm{N}=\mathrm{N}$ bonds in thermal and photochemical isomerizations (Scheme 2), often under mild conditions (sunlight suffices), and assessing the mechanistic aspects by both experiment and theoretical calculations. Overall, this dynamic behavior paves the way to a new class of chiral switches derived from cheap and abundant natural products.

\section{Results and Discussion}

\section{Structure and stereochemistry of monosaccharide azoalkenes}

As mentioned, the synthesis of azoalkenes has been reported elsewhere and involves the formation of aldose arylhydrazones followed by subsequent acetylation and elimination reaction. ${ }^{[10]}$ According to this procedure, $(1 E, 3 E)$-4-(tetra-O-acetyl-Darabino-tetritol-1-yl)-1-aryl-1,2-diaza-1,3-butadienes 4-8 can be obtained from D-mannose and their D-lyxo isomer 9 from Dgalactose, which can be isolated as colored compounds in the solid state and are stable enough, so long as they are protected from heat sources and light. Their initial $(1 E, 3 E)$ configurations (4a-9a) can be inferred from FT-IR and Raman spectra showing the stretching band for the $\mathrm{C}=\mathrm{C}$ bond at $\sim 1650 \mathrm{~cm}^{-1}$. The intense Raman band within $1450-1435 \mathrm{~cm}^{-1}$ has been assigned to the stretching band of the azo group. The other active band in the Raman spectrum, characteristic of the azo group, lying in the range $1160-1140 \mathrm{~cm}^{-1}$, can be attributed to the $\mathrm{N}=\mathrm{N}-\mathrm{Ar}$ symmetric bending (Figures S1-S10, SI). ${ }^{[14]}$<smiles>[R]C(C)C([R])C([R])OC(C)=O</smiles>

$4 \mathbf{a} \times=\mathrm{R}^{1}=\mathrm{H} ; \mathrm{R}^{2}=\mathrm{OAC}$ $\mathbf{5 a X}=\mathrm{OMe} ; \mathrm{R}^{1}=\mathrm{H} ; \mathrm{R}^{2}=O A C$ $\mathbf{6 a} \times=M e ; R^{1}=H ; R^{2}=O A C$ $7 a \mathrm{X}=\mathrm{Cl} ; \mathrm{R}^{1}=\mathrm{H} ; \mathrm{R}^{2}=\mathrm{OAC}$ $\mathbf{8} \mathbf{a X}=\mathrm{Br}^{\mathrm{r}} ; \mathrm{R}^{1}=\mathrm{H} ; \mathrm{R}^{2}=\mathrm{OAC}$ $\mathbf{9 a} \times=\mathrm{R}^{2}=\mathrm{H} ; \mathrm{R}^{1}=\mathrm{OAC}$

$\left(1 E^{\prime} 3 E\right)$

For clarity with the remaining discussion, some NMR data (gathered in Table 1, see also $\mathrm{SI}$ ) should be mentioned as they exhibit a diagnostic value in monitoring the fate of bond isomerisation (Figures S11-S29). The lack of any other 
significant signals in the NMR spectra of $\mathbf{4 a - 9 a}$ indicates that in the dark these substances do exist in only one isomeric form, which can be attributed to the $(1 E, 3 E)$ configuration. This stereochemistry is based on spectroscopic data and thus, the $E$ configuration for the carbon-carbon double bond is supported by the chemical shifts of $\mathrm{H}-1(\sim 7.32 \mathrm{ppm})$ and $\mathrm{H}-2(\sim 6.75 \mathrm{ppm})$ protons and large coupling constants $(\sim 13.5 \mathrm{~Hz}) \cdot{ }^{[15]}$ The $E$ configuration attributed to the diazo moiety is also supported by the shift of the $\mathrm{H}-2$ signal. It has been reported that both $(Z)$ olefinic $^{[15]}$ and (Z)-arylazo ${ }^{[16]}$ compounds are unstable and isomerize to the corresponding $(E, E)$-compounds. Protons $\mathrm{H}-2$ and $\mathrm{H}-3$ consistently show a chemical shift difference of $\sim 0.75$ $0.85 \mathrm{ppm}\left(\Delta \delta_{\mathrm{H}}=\delta_{\mathrm{H} 2}-\delta_{\mathrm{H} 3}\right)$, while for the olefinic carbons that difference is $\sim 13-16 \mathrm{ppm}\left(\Delta \bar{\delta}_{\mathrm{c}}=\delta_{\mathrm{c} 1}-\bar{\delta}_{\mathrm{C} 2}\right)($ Table 1$)$.

Moreover, the unequivocal ground configuration could be corroborated by single-crystal $\mathrm{X}$-ray analyses of compounds $\mathbf{5} \mathbf{a}^{[17]}$ and $\mathbf{6 a} \cdot{ }^{[18]}$ As shown in Figure 1 (see Supporting information), the unit cell of compound $\mathbf{5 a}$ consists of two molecules having each the $(E, E)$ configuration and s-trans disposition between the azo and ethylene groups. To determine the robustness of the stereochemical arrangement, we optimized the structure of $\mathbf{5 a}$ in the gas phase with DFT calculations (Figure 2), and Table 2 compares the experimental distances and bond angles with the calculated ones, which match each other to a significant extent. Both the experimental and calculated data indicate that the azodienic system in $\mathbf{5 a}$ is essentially flat or slightly puckered. The same conclusion can be inferred from the relative dispositions of the azo group and the benzene ring.

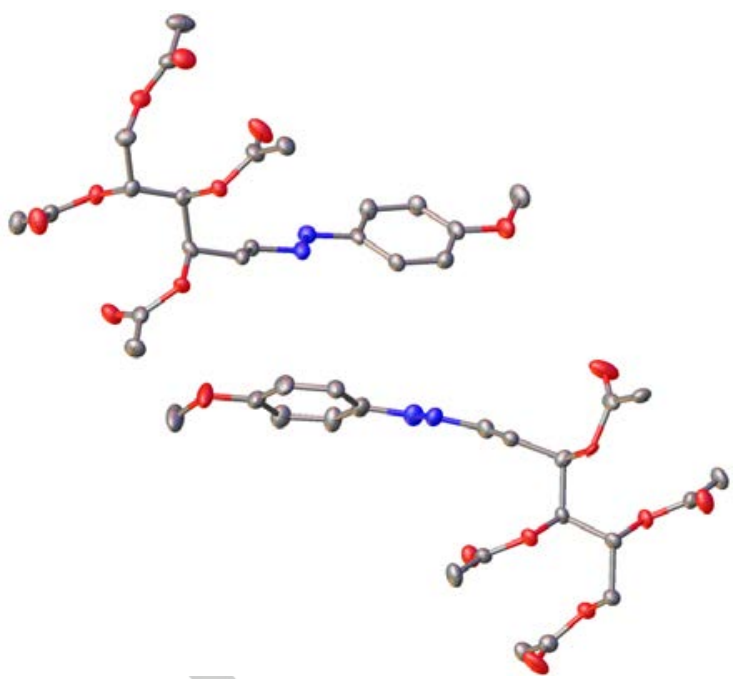

Figure 1. ORTEP diagram for the crystal structure of $\mathbf{5 a}$ with thermal ellipsoids drawn at the $35 \%$ probability. Hydrogen atoms have been omitted for clarity.

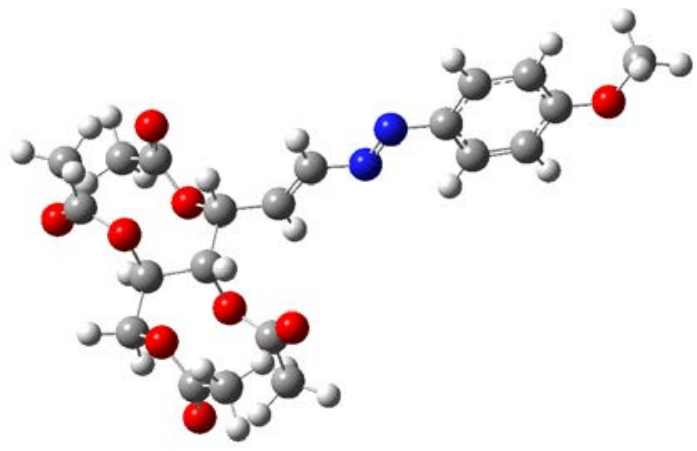

Figure 2. Optimized structure of $\mathbf{5 a}$ (monomer) at the M06-2X/6-311G(d,p) level in the gas phase.

Table 1. Selected NMR data for azoalkenes $4 a-9 a^{[a]}$

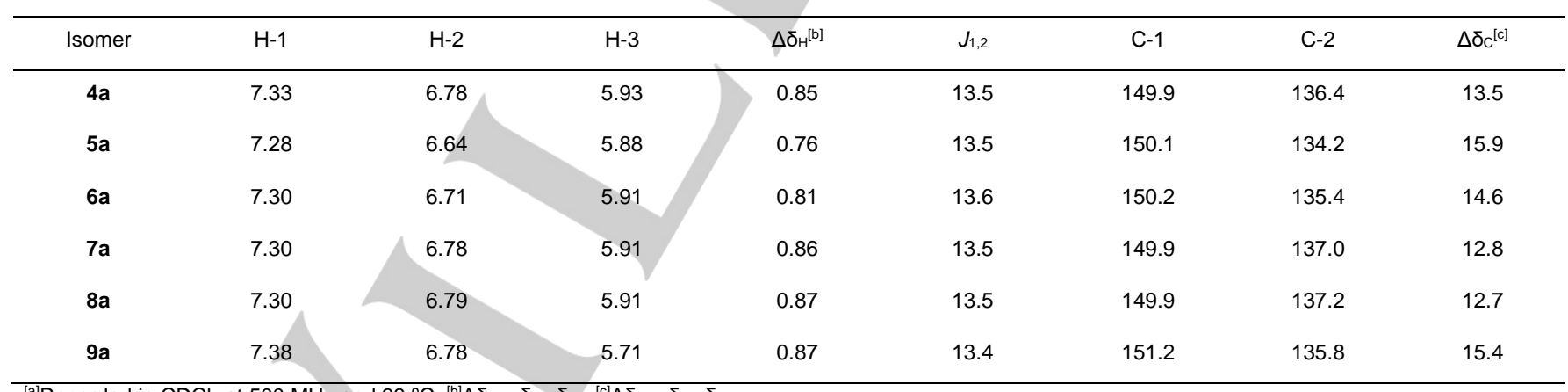

${ }^{[a]}$ Recorded in $\mathrm{CDCl}_{3}$ at $500 \mathrm{MHz}$ and $33{ }^{\circ} \mathrm{C} .{ }^{[\mathrm{b}]} \Delta \delta_{\mathrm{H}}=\delta_{\mathrm{H} 2}-\delta_{\mathrm{H} 3} \cdot{ }^{[\mathrm{cc}} \Delta \delta_{\mathrm{C}}=\delta_{\mathrm{C} 1}-\delta_{\mathrm{C} 2}$. 
Table 2. Experimental and calculated bond distances $(\AA)$ and angles $\left(^{\circ}\right)$ of $\mathbf{5 a}$.

\begin{tabular}{|c|c|c|c|}
\hline & Calculated $^{[\mathrm{a}]}$ & \multicolumn{2}{|c|}{ Experimental (X-ray data) $)^{[b]}$} \\
\hline $\mathrm{N}=\mathrm{N}$ & 1.246 & 1.274 & 1.264 \\
\hline $\mathrm{N}-\mathrm{C}$ & 1.406 & 1.414 & 1.402 \\
\hline$C=C$ & 1.331 & 1.321 & 1.333 \\
\hline $\mathrm{C}-\mathrm{C}$ & 1.494 & 1.499 & 1.503 \\
\hline $\mathrm{C}-\mathrm{N}=\mathrm{N}$ & 114.981 & 113.052 & 112.702 \\
\hline $\mathrm{N}=\mathrm{N}-\mathrm{C}$ & 112.219 & 112.525 & 111.888 \\
\hline $\mathrm{N}-\mathrm{C}=\mathrm{C}$ & 119.488 & 118.669 & 118.168 \\
\hline $\mathrm{C}=\mathrm{C}-\mathrm{C}$ & 122.798 & 121.372 & 121.55 \\
\hline $\mathrm{C}_{\mathrm{ar}}=\mathrm{C}_{\mathrm{ar}}-\mathrm{N}=\mathrm{N}$ & -178.825 & -165.471 & -161.492 \\
\hline $\mathrm{N}=\mathrm{N}-\mathrm{C}=\mathrm{C}$ & -178.21 & -170.556 & -171.503 \\
\hline
\end{tabular}

${ }^{[a]}$ At the M06-2X/6-311G(d,p) level in the gas phase. ${ }^{[b]}$ Each column denotes data for the two monomers present in the unit cell.

\section{Dynamics of chiral azoalkenes in solution}

Remarkably, azoalkenes 4a-9a undergo further evolution in solution, even under mild conditions. Most transformations are driven by an initial $E / Z$ isomerization of the $\mathrm{C}=\mathrm{C}$ bond. Thus, azoalkenes $4 \mathbf{a}-9 \mathbf{a}$ isomerize (in part) into the corresponding $(1 E, 3 Z)$ derivatives $(\mathbf{4 b}-\mathbf{9 b})$ in $\mathrm{CDCl}_{3}$ solution to give after $24 \mathrm{~h}$ a $\sim$ :1 equilibrium mixture (Scheme 3 ), as inferred from ${ }^{1} \mathrm{H}$ and ${ }^{13} \mathrm{C}$ NMR monitoring. This evolution is exemplified by compounds 5 a and 9a (Figures S30-S37) and depicted in Figure 3. All attempts to isolate single isomers failed and led invariably to mixtures of both azoalkenes in variable ratios. The $\mathrm{H}-2$ and $\mathrm{H}-3$ protons are markedly different in both stereoisomers (compare Tables 1 and 3) and their chemical shifts are interchanged, thereby having a diagnostic value as mentioned above. These variations in chemical shift $\left(\Delta \delta_{\mathrm{H}-2} \sim 0.7 \mathrm{ppm}\right.$ and $\left.\Delta \delta_{\mathrm{H}-3} \sim-1.0 \mathrm{ppm}\right)$ agree with data for other azoalkenes. ${ }^{[15]}$ Now, the $\mathrm{H}-2$ and $\mathrm{H}-3$ protons show a chemical shift difference $\left(\Delta \bar{\delta}_{\mathrm{H}}\right)$ of approximately -0.7 to $0.9 \mathrm{ppm}$; that is, the absolute value of $\Delta \delta$ is similar to that for $4 \mathrm{a}$ 9a but negative (Table 3). Moreover, one of the acetate groups (presumably located on C-3) appears appreciably shielded at $\sim 1.90 \mathrm{ppm}$.

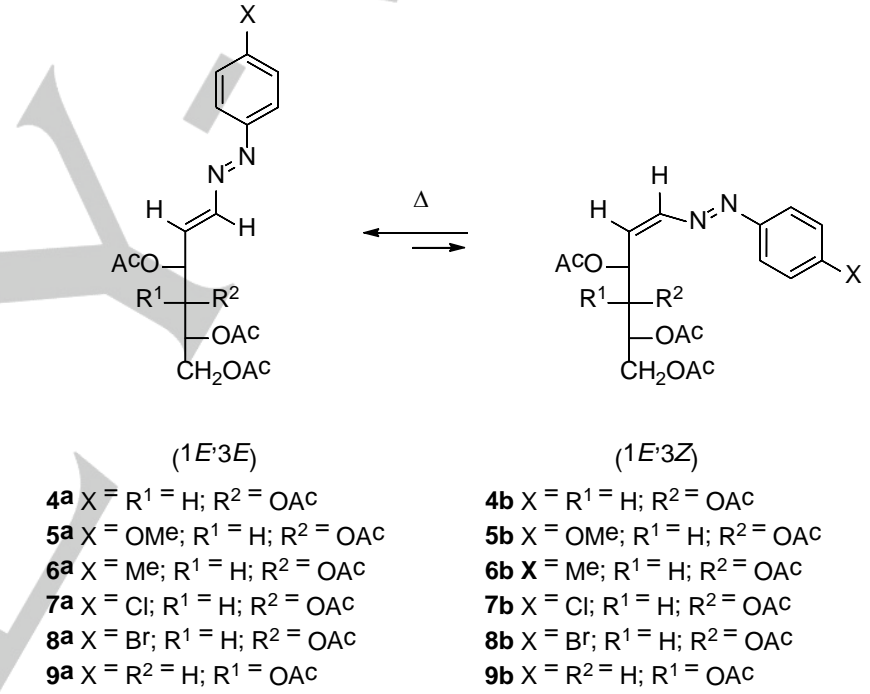

Scheme 3. $\mathrm{E} / \mathrm{Z}$ isomerization of azoalkenes $4 \mathbf{a}-9 \mathrm{a}$ in $\mathrm{CDCl}_{3}$ solution.

Table 3. Population of the minor isomer at the equilibrium and selected NMR data for azoalkenes $4 \mathbf{b}-\mathbf{9} \mathbf{b}^{[\mathrm{a}]}$

\begin{tabular}{|c|c|c|c|c|c|c|c|c|c|c|}
\hline Isomer & {$[3 Z]^{[b]}$} & $\Delta \mathrm{G}_{0}^{[\mathrm{c}]}$ & $\mathrm{H}-1$ & $\mathrm{H}-2$ & $\mathrm{H}-3$ & $\Delta \delta_{H}^{[d]}$ & $J_{1,2}$ & C-1 & $\mathrm{C}-2$ & $\Delta \delta_{c}{ }^{[e]}$ \\
\hline $4 b$ & 18 & 0.94 & 7.21 & 6.10 & 6.89 & -0.80 & 7.7 & 147.6 & 131.9 & 15.7 \\
\hline $5 b$ & 19 & 0.90 & 7.14 & 5.98 & 6.86 & -0.88 & 7.7 & 147.0 & 129.8 & 17.2 \\
\hline $6 b$ & 14 & 1.12 & 7.17 & 6.04 & 6.87 & -0.84 & 8.1 & 147.6 & 130.9 & 16.7 \\
\hline $8 b$ & 8 & 1.51 & 7.18 & 6.12 & 6.75 & -0.72 & 7.6 & 147.6 & 132.6 & 15.0 \\
\hline $9 b$ & 16 & 1.03 & 7.25 & 6.18 & 6.82 & -0.72 & 8.0 & 148.4 & 131.8 & 16.6 \\
\hline
\end{tabular}

${ }^{[\mathrm{a}]} \mathrm{n} \mathrm{CDCl}_{3}$ solution at $500 \mathrm{MHz}$ and $33^{\circ} \mathrm{C}$. ${ }^{[\mathrm{b}]} / \mathrm{n} \%$. ${ }^{[\mathrm{c}]} / \mathrm{n} \mathrm{kcal} / \mathrm{mol} .{ }^{[\mathrm{d}]} \Delta \delta_{\mathrm{H}}=\delta_{\mathrm{H} 2}-\delta_{\mathrm{H} 3} \cdot{ }^{[\mathrm{e}]} \Delta \delta_{\mathrm{C}}=\delta_{\mathrm{C} 1}-\delta_{\mathrm{C} 2}$. 
$\mathrm{H}-1$

b

H-1 H-2 H-3

$H-3$
H-2

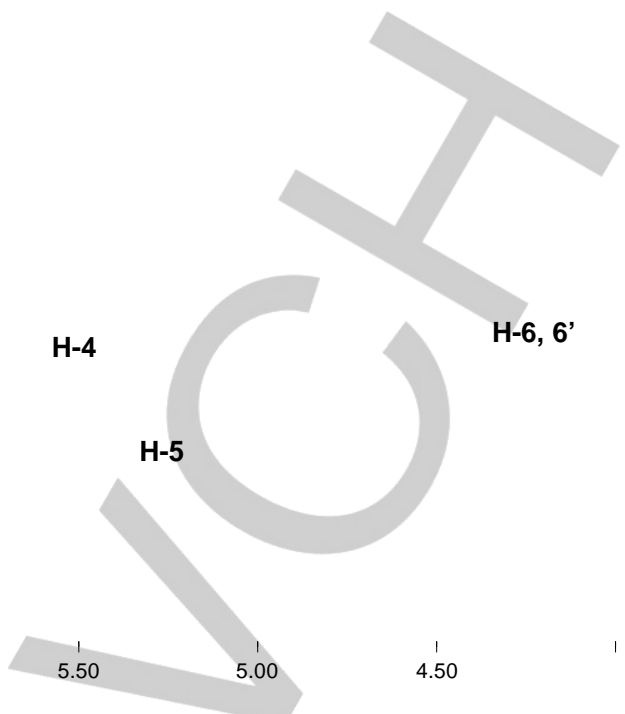

Figure 3. Evolution of compound $\mathbf{5 a}$ in solution $\left({ }^{1} \mathrm{H}\right.$ NMR spectrum in $\mathrm{CDCl}_{3}$ at $500 \mathrm{MHz}$ ): (a) just-dissolved sample; (b) after equilibration with its isomer $\mathbf{5 b}$.

As expected, the coupling constants are also useful in assessing this configurational change, because for the olefinic protons $J$ varies from $\sim 13.5 \mathrm{~Hz}(1 E, 3 E$ configuration) to $8 \mathrm{~Hz}$ in the isomerized $(1 E, 3 Z)$ azoalkene. In addition, the upfield chemical shifts observed for the C-1 and C-2 signals are instrumental when one moves from a $(1 E, 3 E)$ configuration to its isomeric $(1 E, 3 Z)$ form $\left(\left|\Delta \delta_{\mathrm{c}-1}\right| \sim 2.5-3 \mathrm{ppm}\right.$ and $\left.\left|\Delta \delta_{\mathrm{c}-2}\right| \sim 4-5 \mathrm{ppm}\right)$. However, the difference of the olefinic carbons is similar to that shown by $4 \mathbf{a}-9 \mathbf{a}$ (15-17 ppm) (see Table 3 ). These results in $\mathrm{CDCl}_{3}$ agree with the pattern observed for other azoalkenes, ${ }^{[15,16]}$ although they disagree with those of Jørgensen and Pedersen, who in a further study reported that azoalkene $\mathbf{4 a}$ in $\mathrm{CDCl}_{3}$ solution undergoes $\mathrm{ZIE}$ isomerization around the $\mathrm{N}=\mathrm{N}$ bond as both isomers show trans-2,3-couplings of $13.5 \mathrm{~Hz} .^{[19]}$ However, the present reinvestigation of $\mathbf{4 a}$ points clearly to the same behaviour as compounds $\mathbf{5 a - 9 a}$, in terms of both chemical shifts and coupling constants (data collected in Tables 1 and 3).

\section{Photoisomerization of azoalkenes}

(1E,3E)-Azoalkenes 4a-9a undergo partial isomerization when their benzene solutions are irradiated with sunlight (Scheme 4). After a few minutes of light exposure a photostationary state is attained, constituted by a mixture of two isomers $(\sim 10: 1$, Table 4). UV-V spectra of 4a-9a show absorptions at $\sim 340-300 \mathrm{~nm}$ corresponding to the $\pi \rightarrow \pi^{*}$ transition and responsible for their photoisomerization. ${ }^{[10 a]}$ Consistent with spectroscopic data, the emerging isomers $\mathbf{4 c} \mathbf{c}-9 \mathbf{c}$ should have the $(1 Z, 3 E)$ configuration because their large coupling constants $\left(J_{1,2} \sim 13.5 \mathrm{~Hz}\right)$ are coincidental with those of the $(1 E, 3 E)$ isomers (Table 4$)$. In fact, all coupling constants show an identical pattern. Furthermore, the olefinic protons and $\mathrm{H}-3$ exhibit small chemical shift variations with respect to $4 \mathrm{a}-9 \mathbf{a}\left(\Delta \delta_{\mathrm{H}-1}\right.$ and $\Delta \delta_{\mathrm{H}-2}<0.2 \mathrm{ppm}$, and $\left.\left|\Delta \delta_{\mathrm{H}-3}\right|<0.3 \mathrm{ppm}\right)$, whereas there is a strong shielding effect for the ortho protons at the aromatic ring $\left(\left|\Delta \delta_{\text {Horto }}\right| \sim 1.0 \mathrm{ppm}\right) .{ }^{1} \mathrm{H}$ NMR, COSY and HMQC spectra of $4 \mathrm{a}-9 \mathrm{a}$ after $1 \mathrm{~h}$ of light exposure is gathered in Figures S38 and S53 (see $\mathrm{SI}$ ).

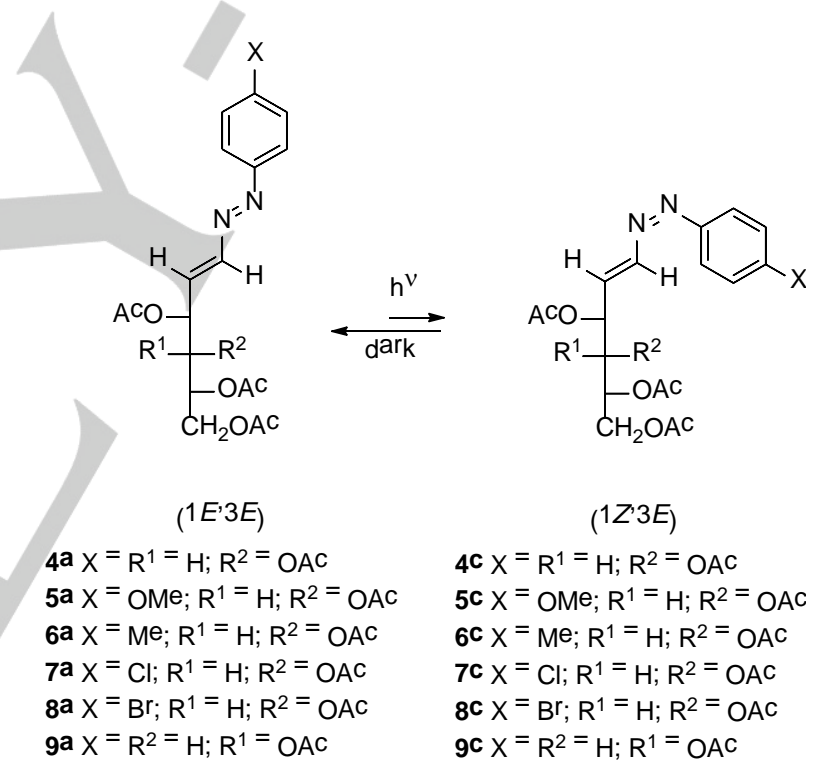

Scheme 4. Photoisomerization of azoalkenes $4 \mathbf{a}-9 \mathbf{a}$ in benzene solution.

In the subsequent $24 \mathrm{~h}$ after sunlight exposure (for $1 \mathrm{~h}$ ), another stereoisomer could be detected in the reaction mixture, whose configuration at the azoalkene moiety should be $(1 E, 3 Z)$ as supported by a lower $J_{1,2}$ coupling $(-8.0 \mathrm{~Hz})$ and the corresponding chemical shifts (the $\mathrm{H}-2$ proton resonates at $\sim 6.8$ ppm and $\mathrm{H}-3$ at $\sim 5.9 \mathrm{ppm}$ ). When the azoalkene-containing mixture is stored in the dark the $(1 Z, 3 E)$ isomer gradually disappears, thus evidencing its lower thermodynamic stability relative to the other azoalkenes. This behavior is well illustrated by the evolutionary conversion of $\mathbf{5 a}$ in benzene solution (Figure 4). After exposing the flask to sunlight radiation, a mixture of $\mathbf{5 a} / \mathbf{5 c}$ in $94: 6$ ratio can be identified. After $24 \mathrm{~h}$ in the dark, the resulting stereoisomeric mixture contains a distribution of $\mathbf{5 a}$ $(1 E, 3 E), \mathbf{5 b}(1 E, 3 Z)$, and $\mathbf{5 c}(1 Z, 3 E)$ in a $92: 2: 6$ ratio.

The identification of $5 \mathbf{b}(1 E, 3 Z)$ demands a further rationale, as its formation in the dark without acid catalysis is not immediately 
obvious. Such acid conditions cannot be completely excluded and minor degradation at the azoalkene moiety could take place. The $(1 Z, 3 E)$ isomer might also be involved, albeit this surmise should be taken with caution in the absence of clear-cut evidences. The fact that the $(1 Z, 3 E)$ isomer relaxes into $(1 E, 3 E)$ form in the dark, even without any acid catalysis, does suggest that the Z-azo bond might relax faster in the presence of acid traces. Overall, formation of the $(1 E, 3 Z)$ isomer would proceed through the same intermediate (vide infra, acid-catalyzed mechanism).

Table 4. Selected NMR data for $(1 Z, 3 E)$-configured azoalkenes $4 c-9 c^{[a]}$

\begin{tabular}{|c|c|c|c|c|c|c|c|c|c|}
\hline Isomer & {$[1 Z]^{[\mathrm{b}]}$} & $\mathrm{H}-1$ & $\mathrm{H}-2$ & $\mathrm{H}-3$ & $\Delta \delta_{H}^{[c]}$ & $J_{1,2}$ & C-1 & C-2 & $\Delta \delta_{c}{ }^{[d]}$ \\
\hline $4 c$ & 10 & 7.23 & 6.93 & 5.74 & 1.19 & 13.5 & 141.7 & 138.5 & 3.2 \\
\hline $5 c$ & 6 & 7.38 & 6.87 & 5.79 & 1.08 & 13.5 & 142.5 & 135.9 & 6.6 \\
\hline $6 c$ & 7 & 7.32 & 6.79 & 5.76 & 1.15 & & 142.1 & 137.4 & 4.7 \\
\hline $8 c$ & 9 & 7.10 & 6.91 & 5.75 & 1.16 & 13.5 & 141.6 & 139.2 & 2.4 \\
\hline $9 c$ & 10 & 7.28 & 6.96 & 5.49 & 1.47 & 13.5 & 142.6 & 138.1 & 4.5 \\
\hline
\end{tabular}

${ }^{[a]}$ Recorded in $\mathrm{C}_{6} \mathrm{D}_{6}$ at $500 \mathrm{MHz}$ and $33{ }^{\circ} \mathrm{C}$. $\left.{ }^{[b]}\right] \mathrm{n} \% .{ }^{[c]} \Delta \delta_{H}=\delta_{H 1}-\delta_{H 2} \cdot{ }^{[d]} \Delta \delta_{\mathrm{C}}=\delta_{\mathrm{C} 1}-\delta_{\mathrm{C} 2}$.

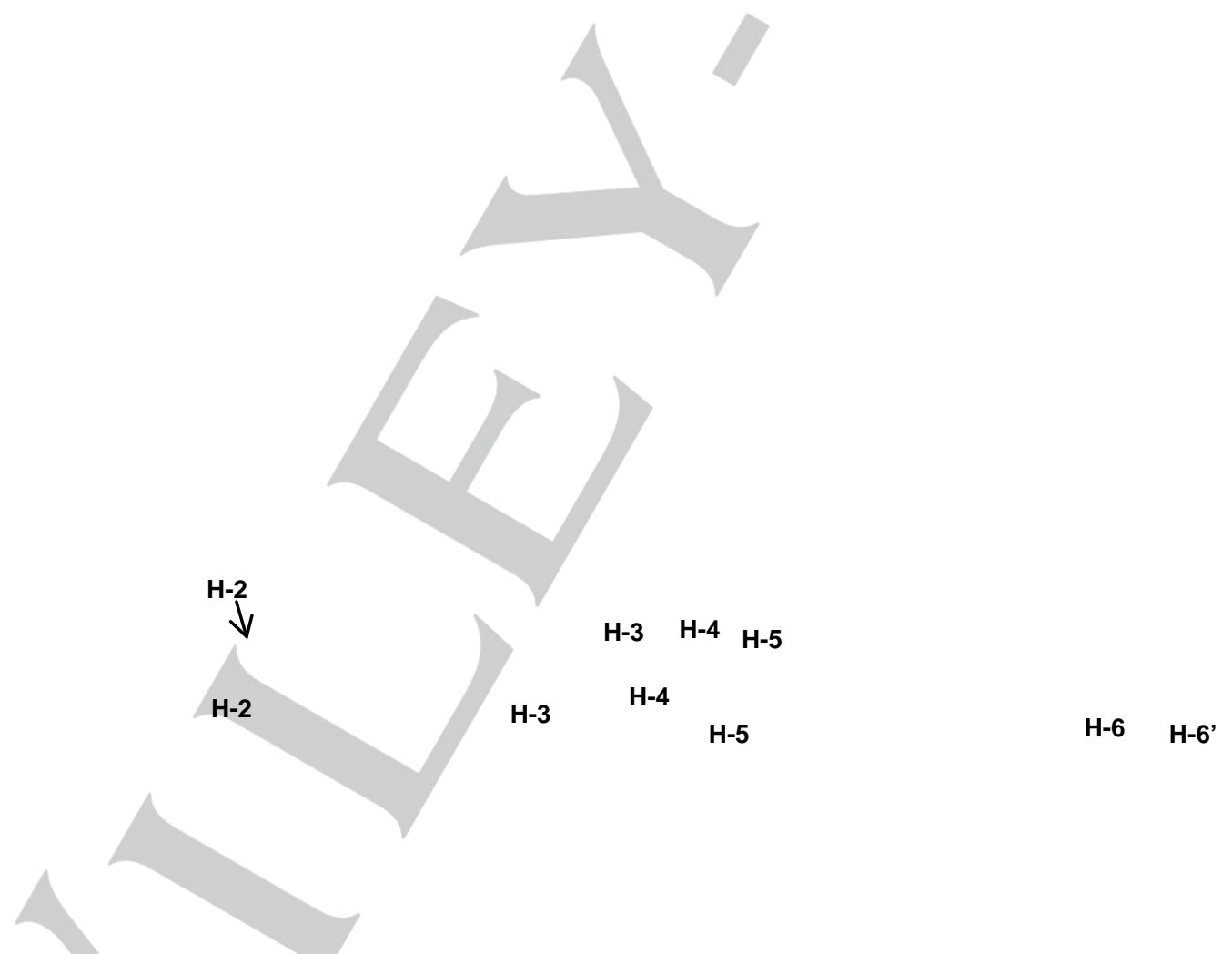

Figure 4. Evolution of compound $\mathbf{5 a}$ in $\mathrm{C}_{6} \mathrm{D}_{6}$ solution: (a) just dissolved; (b) after $1 \mathrm{~h}$ of solar irradiation; (c) after $24 \mathrm{~h}$ in the dark; (d) after 5 days in the dark.

After prolonged storing in the dark ( 5 days) the isomeric composition moves to $96: 3: 1$. The $(1 Z, 3 E)$ isomer has virtually disappeared, while the $(1 E, 3 Z)$-configured azoalkene remains unaffected; a fact supporting the slow conversion of $\mathbf{5 c}$ into $\mathbf{5 a}$ in the dark. The same $1 E \rightarrow 1 Z$ photoisomerization can be observed in DMSO- $d_{6}(\sim 7 \%)$ and perdeuterated acetone $(\sim 8 \%)$. However, under solar irradiation in $\mathrm{CDCl}_{3}$ only the $(1 E, 3 Z)$ isomer could be detected $(7 \%)$. As rule of thumb, the azo group of azoalkenes is prone to $1 E \rightarrow 1 Z$ photoisomerization when irradiated with sunlight whereas the opposite $1 Z \rightarrow 1 E$ isomerization occurs thermally in the dark.

\section{Stability of azoalkene stereoisomers}


Table 3 collects the equilibrium composition of $(1 E, 3 E) /(1 E, 3 Z)$ configured azoalkenes. At the experimentally measured temperature $\left(33^{\circ} \mathrm{C} ; 306 \mathrm{~K}\right)$ their difference in stability can easily be assessed by $\Delta G_{0}=-R T I n K_{e}$, where $K_{e}=[E] /[Z]$. On using the above tabulated data, we found energy differences ranging from 0.9 to $1.5 \mathrm{kcal} / \mathrm{mol}$, favoring invariably the $(1 E, 3 E)$ stereoisomer.
A computational study has been undertaken to determine the relative stability of all stereoisomers involving double bond configurations; namely $(1 E, 3 E)(\mathbf{a}),(1 E, 3 Z)(\mathbf{b})$ and $(1 Z, 3 E)(\mathbf{c})$ which have been observed experimentally, and also $(1 Z, 3 Z)$ azoalkenes (d).

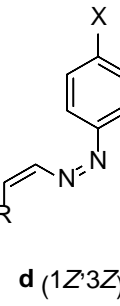<smiles>[R]C=CN=Nc1ccc([X])cc1</smiles><smiles>[R]C=CN=Nc1ccc([X])cc1</smiles>

$\mathbf{a}_{\left(1 E^{\prime} 3 E^{\prime}\right)}$<smiles>[R]C=CN=Nc1ccc([X])cc1</smiles>

$\mathbf{c}_{\left(1 Z^{\prime} 3 E\right)}$

Initially, gas-phase theoretical calculations with complete geometry optimization at the M06-2X/6-311G(d,p) level, ${ }^{[20,21]}$ as implemented in the Gaussian09 package of programs, ${ }^{[22]}$ were performed to ascertain the relative stability of diastereomeric structures for model compounds $\mathbf{1 0 - 1 2}$, as well as the electronic influence exerted by the aliphatic substituents and their propensity to interconvert. Further calculations of vibrational frequencies have also been performed to estimate the isomerization energies in terms of free energies. Bulk solvation (through dielectric constants for $\mathrm{C}_{6} \mathrm{H}_{6}, \mathrm{CHCl}_{3}$, and DMSO) has also been assessed with the usual solvation model based on density (SMD). ${ }^{[23]}$ The relative stabilities of the different diastereomers of 10-12 are summarized in Table 5, which reflect the greater stability of the $(1 E, 3 E)$ isomer in the cases of 10 and 11 and approximately equal stability between the $(1 E, 3 E)$ and $(1 E, 3 Z)$ isomers of 12 . Azoalkenes $(1 Z, 3 E)$ and $(1 Z, 3 Z)$, showing similar stability, are however appreciably less stable

than the corresponding $(1 E, 3 E)$ and $(1 E, 3 Z)$ diastereomers by more than $10 \mathrm{kcal} / \mathrm{mol}$.

The gas-phase calculations for compounds $\mathbf{4}, \mathbf{5}, \mathbf{7}$, and $\mathbf{9}$ predict a greater stability of $(1 E, 3 E)$ and $(1 E, 3 Z)$ diastereomers than their $(1 Z, 3 E)$ and $(1 Z, 3 Z)$ counterparts. Isomerization around the double carbon-carbon bond causes a minor change on moving from $(1 E, 3 E)$ to $(1 E, 3 Z)$ or from $(1 Z, 3 E)$ to $(1 Z, 3 Z)$ configurations $\left[\Delta G_{1 E, 3 E \leftrightarrow 1 E, 3 Z}\right.$ and $\left.\Delta G_{1 Z, 3 E \leftrightarrow 1 Z, 3 Z}<|2.3| \mathrm{kcal} / \mathrm{mol}\right]$. In stark contrast, the isomerization around the $\mathrm{N}=\mathrm{N}$ bond leads to much more significant variations $\left[\Delta \mathrm{G}_{1 E, 3 E \leftrightarrow 1 Z, 3 E}>|8| \mathrm{kcal} / \mathrm{mol}\right.$ and $\Delta \mathrm{G}_{1 E, 3 Z \leftrightarrow 1 Z, 3 Z}>|12| \mathrm{kcal} / \mathrm{mol}$. Such a destabilization could be ascribed on the one hand to the steric repulsion between the ortho hydrogens, relative to the azo group, and the vinyl hydrogen at $\mathrm{C}-1$, and on the other to the steric repulsion between lone pairs on the azo functional group when they adopt an eclipsed arrangement in the (1Z) configuration. ${ }^{[24]}$ Both repulsive effects disappear on adopting the $(1 E)$ configuration.

Table 5. Relative stability of diastereomeric azoalkene structures ${ }^{[a, b}$

\begin{tabular}{|c|c|c|c|c|c|c|c|c|c|c|}
\hline \multicolumn{2}{|c|}{ Configurations } & & \multicolumn{2}{|c|}{$\mathbf{a}(1 E, 3 E)$} & \multicolumn{2}{|c|}{$\mathbf{b}(1 E, 3 Z)$} & \multicolumn{2}{|c|}{$\mathbf{c}(1 Z, 3 E)$} & \multicolumn{2}{|c|}{$\mathbf{d}(1 Z, 3 Z)$} \\
\hline Compound & $x$ & $\varepsilon$ & $\Delta \mathrm{E}$ & $\Delta \mathrm{G}$ & $\Delta \mathrm{E}$ & $\Delta \mathrm{G}$ & $\Delta \mathrm{E}$ & $\Delta \mathrm{G}$ & $\Delta \mathrm{E}$ & $\Delta \mathrm{G}$ \\
\hline $4^{[c]}$ & $\mathrm{H}$ & 1 & 2.08 & 2.17 & 0.00 & 0.00 & 11.41 & 12.54 & 11.90 & 12.06 \\
\hline $4^{[d]}$ & $\mathrm{H}$ & 2.3 & 2.02 & 1.66 & 0.00 & 0.00 & 11.87 & 11.57 & 11.92 & 11.16 \\
\hline $4^{[\mathrm{e}]}$ & $\mathrm{H}$ & 4.8 & 1.32 & 0.50 & 0.00 & 0.00 & 10.49 & 9.87 & 11.26 & 10.28 \\
\hline $4^{[f]}$ & $\mathrm{H}$ & 46.7 & 0.27 & 0.00 & 0.00 & 0.13 & 9.18 & 8.82 & 10.48 & 10.90 \\
\hline $5^{[c]}$ & $\mathrm{OMe}$ & 1 & 2.14 & 1.45 & 0.00 & 0.00 & 12.74 & 13.08 & 11.59 & 12.20 \\
\hline $5^{[\mathrm{d}]}$ & OMe & 2.3 & 2.01 & 2.28 & 0.00 & 0.00 & 13.06 & 13.93 & 11.77 & 13.42 \\
\hline $5^{[e]}$ & OMe & 4.8 & 1.49 & 2.18 & 0.00 & 0.00 & 11.62 & 12.94 & 11.09 & 12.62 \\
\hline $5^{[f]}$ & $\mathrm{OMe}$ & 46.7 & 0.78 & 0.20 & 0.00 & 0.00 & 10.10 & 11.42 & 10.18 & 11.27 \\
\hline $7^{[c]}$ & $\mathrm{Cl}$ & 1 & 1.80 & 1.38 & 0.00 & 0.00 & 11.30 & 11.33 & 10.94 & 12.17 \\
\hline $7^{[\mathrm{d}]}$ & $\mathrm{Cl}$ & 2.3 & 1.72 & 2.33 & 0.00 & 0.00 & 11.67 & 12.89 & 11.24 & 12.16 \\
\hline $7^{[\mathrm{e}]}$ & $\mathrm{Cl}$ & 4.8 & 1.16 & 2.11 & 0.00 & 0.00 & 10.26 & 11.99 & 10.46 & 13.01 \\
\hline $7^{[f]}$ & $\mathrm{Cl}$ & 46.7 & 0.65 & 2.14 & 0.00 & 0.00 & 9.13 & 10.59 & 9.60 & 12.46 \\
\hline
\end{tabular}




\begin{tabular}{|c|c|c|c|c|c|c|c|c|c|c|}
\hline $\mathbf{9}^{[c]}$ & $\mathrm{H}$ & 1 & 0.00 & 0.00 & 0.29 & 0.43 & 12.52 & 11.85 & 14.27 & 13.97 \\
\hline $9^{[d]}$ & $\mathrm{H}$ & 2.3 & 0.00 & 0.00 & 0.53 & 1.37 & 12.20 & 12.25 & 13.63 & 13.98 \\
\hline $9^{[e]}$ & $\mathrm{H}$ & 4.8 & 0.00 & 0.00 & 0.63 & 1.01 & 11.27 & 11.55 & 12.69 & 13.85 \\
\hline $\mathbf{9}^{[f]}$ & $\mathrm{H}$ & 46.7 & 0.00 & 0.00 & 0.79 & 1.86 & 10.18 & 10.08 & 11.23 & 11.68 \\
\hline $10^{[c]}$ & OMe & 1 & 0.00 & 0.00 & 0.36 & 0.46 & 12.84 & 12.25 & 12.76 & 12.29 \\
\hline $11^{[c]}$ & $\mathrm{H}$ & 1 & 0.00 & 0.00 & 0.41 & 1.10 & 11.80 & 11.33 & 11.88 & 12.33 \\
\hline $12^{[\mathrm{c}]}$ & $\mathrm{NO}_{2}$ & 1 & 0.00 & 0.10 & 0.46 & 0.00 & 11.53 & 11.44 & 11.82 & 11.74 \\
\hline
\end{tabular}

${ }^{[\mathrm{a}]}$ In kcal/mol. ${ }^{[\mathrm{b}]} \mathrm{At}$ the M06-2X/6-311G(d,p) level. ${ }^{[\mathrm{c}]}$ In the gas phase. ${ }^{[\mathrm{d}]}$ Including the solvent effect (SMD model, benzene as solvent, $\left.\varepsilon=2.3\right)$. ${ }^{\left[{ }^{e}\right]} / \mathrm{ncluding}$ the solvent effect ( $\mathrm{SMD}$ model, $\mathrm{CHCl}_{3}$ as solvent, $\left.\varepsilon=4.8\right)$. ${ }^{[\mathrm{fI}}$ Including the solvent effect (SMD model, DMSO as solvent, $\varepsilon=46.7$ ).

Inclusion of solvent effects does not alter appreciably the results found for compounds $\mathbf{4}, \mathbf{5}, \mathbf{7}$, and $\mathbf{9}$ in the gas phase. Computation reveals that the $(1 E, 3 E)$ and $(1 E, 3 Z)$ diastereomers have nearly identical energies. However, an increase in the polarity of the solvent also increases the stability of the isomer $(1 E, 3 E)$. This agrees relatively well with experimental data in $\mathrm{CHCl}_{3}$ solution for 4-9, because only $(1 E, 3 E)$ - and $(1 E, 3 Z)$ configured azoalkenes could be observed. Despite the high energy gap between $(1 Z, 3 E)$ and $(1 E, 3 E)$ isomers, sunlight irradiation provides enough activation to generate the former. This pronounced difference in stability justifies otherwise the transformation in the dark into the more stable all-(E)-configured azoalkenes.

Lastly, it is pertinent to emphasize that model compounds 10-12 evidence the enhanced stability of $(1 E, 3 E)$ isomers, a trend verified in part for azoalkenes bearing a polyacetoxyl side chain. The observed discrepancy may be due in part to the presence of this chain, which can adopt a large number of conformations that have not been calculated to reduce the high computational cost involved. In addition, the model used to simulate solvent effects (bulk solvation) might not be appropriate as no discrete interactions with a given number of solvent molecules were taken into account either.

\section{Conformational analysis}

Given the acyclic nature of the sugar side chain, to gain further insights into azoalkene stability, a conformational study has been performed on the four diastereomers of $\mathbf{1 1}$ (Figure 6), structure devoid of substitution at the aromatic ring, together with the $(1 E, 3 E)$ and $(1 E, 3 Z)$ isomers of 5 .

To this end the rotational energy, calculated through $15^{\circ}$-steps, around the dihedral angle $\theta_{\mathrm{N} 1-\mathrm{N} 2-\mathrm{C} 1-\mathrm{C} 2}$ has been determined. Conformational minima and maxima have been estimated without any geometrical restriction; with maxima identified by frequency analysis (they show one and only one imaginary frequency). The resulting conformational profiles are collected in Figures 5 and 7 and Table 6 shows the energy values for both minima and maxima.

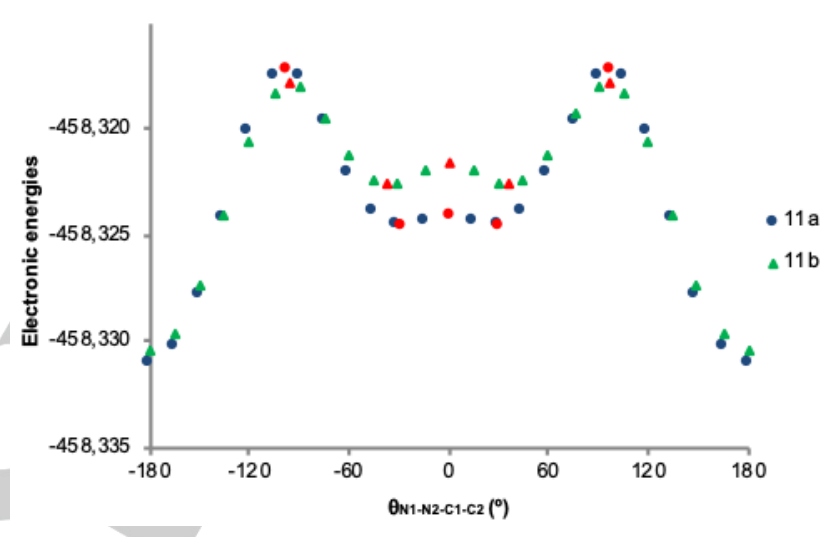

Figure 5. Conformational analyses of $11 \mathbf{a}(1 E, 3 E$ isomer) and $11 \mathbf{b}(1 E, 3 Z$ isomer) by rotation around the dihedral angle $\theta_{\mathrm{N} 1-\mathrm{N} 2-\mathrm{C1}-\mathrm{C2} \text {. Minima and maxima }}$ (labeled in red) have been calculated without geometrical restrictions.

The conformational profiles for $\mathbf{1 1 a} / \mathbf{1 1} \mathbf{b}$ and $\mathbf{1 1} \mathbf{c} / \mathbf{1 1 d}$ are almost coincidental, with the s-trans arrangement $\left(\theta_{\mathrm{N} 1-\mathrm{N} 2-\mathrm{C} 1-\mathrm{C} 2} \sim 180^{\circ}\right)$ being the most stable conformer $(>3.4 \mathrm{kcal} / \mathrm{mol})$. Twisted s-cis conformers show a dihedral angle $\theta_{\mathrm{N} 1-\mathrm{N} 2-\mathrm{C} 1-\mathrm{C} 2}$ of $\sim 30-35^{\circ}$ for azoalkenes featuring both $(1 E, 3 E)$ and $(1 E, 3 Z)$ configurations, while this angle is greater $\left(-55-60^{\circ}\right)$ for $11 \mathrm{c}(1 Z, 3 E)$ and $11 \mathrm{~d}$ $(1 Z, 3 Z)$ due to an increase of repulsive effects at $\theta \sim 0^{\circ}$ (moving from 9 to $17 \mathrm{kcal} / \mathrm{mol}$ ). However, those twisted $\mathrm{s}$-cis conformations should be adopted for hetero-Diels-Alder to occur and show low interconversion barriers. ${ }^{[25,26]}$ For comparative effects, the conformational behavior of the most stable stereoisomers $\mathbf{5 a}$ and $\mathbf{5 b}$ has been evaluated and the resulting profiles are similar to those of $\mathbf{1 1 a}$ and $\mathbf{1 1 b}$ (Figure 8).

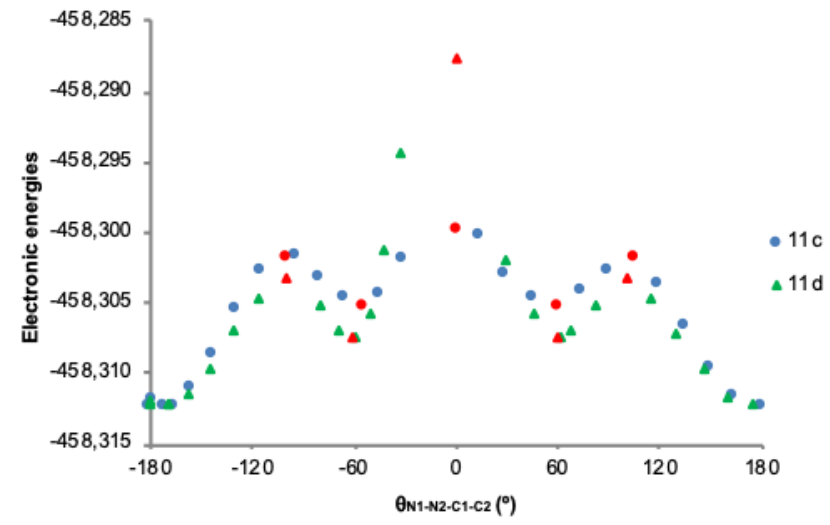


Figure 7. Conformational analyses of $11 \mathbf{c}(1 Z, 3 E$ isomer) and $11 \mathbf{d}(1 Z, 3 Z$

isomer) by rotation around the dihedral angle $\theta_{\mathrm{N} 1-\mathrm{N} 2-\mathrm{C} 1-\mathrm{C} 2}$. Minima and maxima (labeled in red) have been calculated without geometrical restrictions.

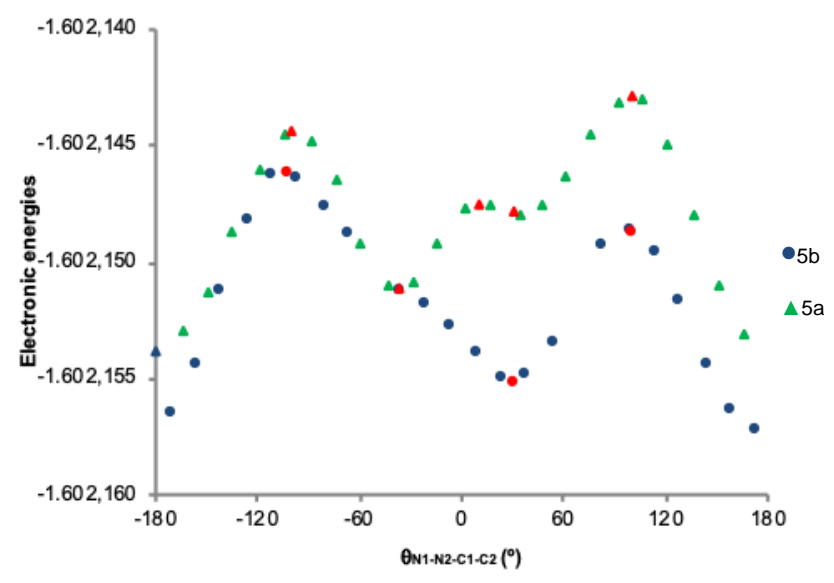

Figure 8. Conformational analysis of $\mathbf{5 a}(1 E, 3 E$ isomer) and $\mathbf{5 b}(1 E, 3 Z$

isomer) by rotation around the diedral angle $\theta_{N 1-N 2-C 1-C 2}$. Minima and maxima (labeled in red) have been calculated without geometrical restrictions.

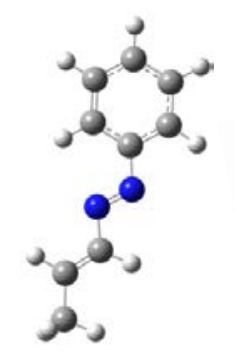

$(1 E, 3 E)$

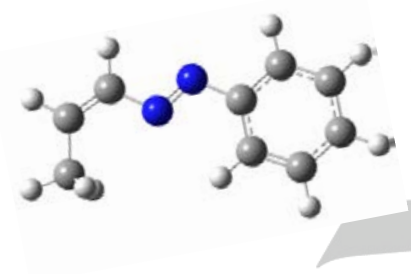

$(1 E, 3 Z)$

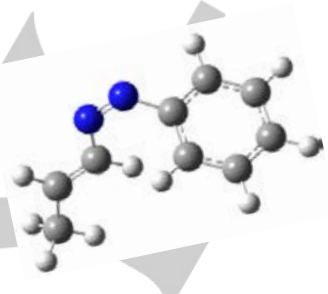

$(1 Z, 3 E)$

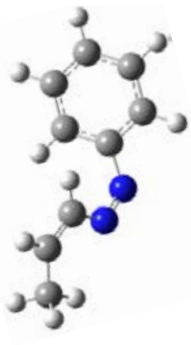

$(1 Z, 3 Z)$

Figure 6. Optimized structures for geometrical isomers of $\mathbf{1 1}$ in the gas phase. 
Table 6. Relative stability of conformers derived from azoalkenes $\mathbf{1 1 a}, \mathbf{1 1} \mathbf{b}, \mathbf{5 a}$ and $\mathbf{5} \mathbf{b}^{[\mathrm{a}]}$

\begin{tabular}{|c|c|c|c|c|c|c|c|}
\hline & $\theta^{[\mathrm{b}]}$ & $0.0^{\circ}$ & $29.4^{\circ}$ & $97.1^{\circ}$ & $180.0^{\circ}$ & $262.9^{\circ}$ & $330.6^{\circ}$ \\
\hline \multirow[t]{3}{*}{$11 \mathbf{a}(1 E, 3 E)$} & $\Delta \mathrm{E}^{[\mathrm{c}]}$ & 4.45 & 4.16 & 8.77 & 0.00 & 8.77 & 4.16 \\
\hline & $\Delta \mathrm{G}^{[\mathrm{c}]}$ & 5.07 & 4.27 & 8.69 & 0.00 & 8.69 & 4.28 \\
\hline & $\theta^{[\mathrm{b}]}$ & $0.0^{\circ}$ & $36.6^{\circ}$ & $95.8^{\circ}$ & $179.9^{\circ}$ & $264.2^{\circ}$ & $323.4^{\circ}$ \\
\hline \multirow[t]{3}{*}{ 11b $(1 E, 3 Z)$} & $\Delta \mathrm{E}^{[\mathrm{c}]}$ & 5.57 & 4.94 & 8.01 & 0.00 & 8.01 & 4.94 \\
\hline & $\Delta \mathrm{G}^{[c]}$ & 6.58 & 4.87 & 7.40 & 0.00 & 7.40 & 4.87 \\
\hline & $\theta^{[\mathrm{b}]}$ & $10.2^{\circ}$ & $34.7^{\circ}$ & $100.0^{\circ}$ & $181.3^{\circ}$ & $261.0^{\circ}$ & $322.5^{\circ}$ \\
\hline \multirow[t]{2}{*}{$5 \mathbf{a}(1 E, 3 E)$} & $\Delta \mathrm{E}^{[\mathrm{c}]}$ & 3.97 & 3.71 & 6.84 & 0.00 & 5.91 & 1.73 \\
\hline & $\Delta \mathrm{G}^{[\mathrm{c}]}$ & 4.53 & 2.67 & 6.67 & 0.00 & 5.78 & 2.35 \\
\hline \multirow[t]{2}{*}{$5 \mathbf{b}(1 E, 3 Z)$} & $\Delta \mathrm{E}^{[\mathrm{c}]}$ & & 1.32 & 5.38 & 0.00 & 6.95 & \\
\hline & $\Delta \mathrm{G}^{[\mathrm{c}]}$ & & 1.57 & 5.67 & 0.00 & 6.09 & \\
\hline
\end{tabular}

${ }^{1} \mathrm{H} \quad$ NMR data for stereoisomers $\mathbf{a}(1 E, 3 E), \mathbf{b}(1 E, 3 Z)$ and $\mathbf{c}(1 Z, 3 E)$ of compounds 4-9 allow us to elucidate the conformational preference in solution. Previous work dealing with simple azoalkenes indicated that the photochemical transformation of $(1 E, 3 Z)$-phenylazocyclohexene into its $(1 Z, 3 Z)$ stereoisomer causes a significant variation of the olefinic resonance $\left(\Delta \delta_{\mathrm{H}-2} \sim 1.5 \mathrm{ppm}\right)$, a fact rightly attributed to the effective shielding generated by the aromatic ring placed in nonplanar arrangement with the $\mathrm{N}=\mathrm{N}$ bond in the twisted $\mathrm{s}$-cis conformation (Scheme 5). ${ }^{[15]}$ The latter, however, contrasts with the photoisomerization of $4 \mathbf{a}-\mathbf{9 a}$, for which chemical shift variations experienced by the $\mathrm{H}-2$ proton are negligible $\left(\Delta \bar{\delta}_{\mathrm{H}-2} \leq\right.$ $0.27 \mathrm{ppm}$ ). Accordingly, the preferential conformation adopted by $4 c-9 c$ in solution should be s-trans; as the opposite $s$-cis disposition would have caused a substantial shielding of the $\mathrm{H}-2$ signal $\left(\delta_{\mathrm{H}-2} \sim 5.4 \mathrm{ppm}\right)$ (Scheme 6$)$. Such conclusive statements agree with the theoretical calculations collected in Tables 5 and 6 pointing to s-trans conformations as the most stable arrangement. The remaining framework should have the same conformation as that of $(1 E, 3 E)$ isomers because of identical coupling constants.

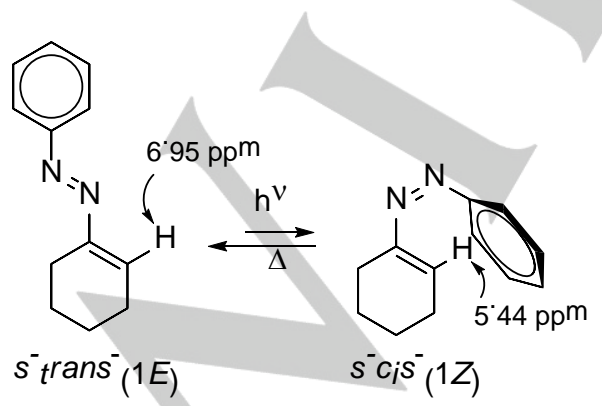

Scheme 5. Proton shift variation of the olefinic resonance in the photochemical transformation of phenylazocyclohexene, taken from Ref. [15].

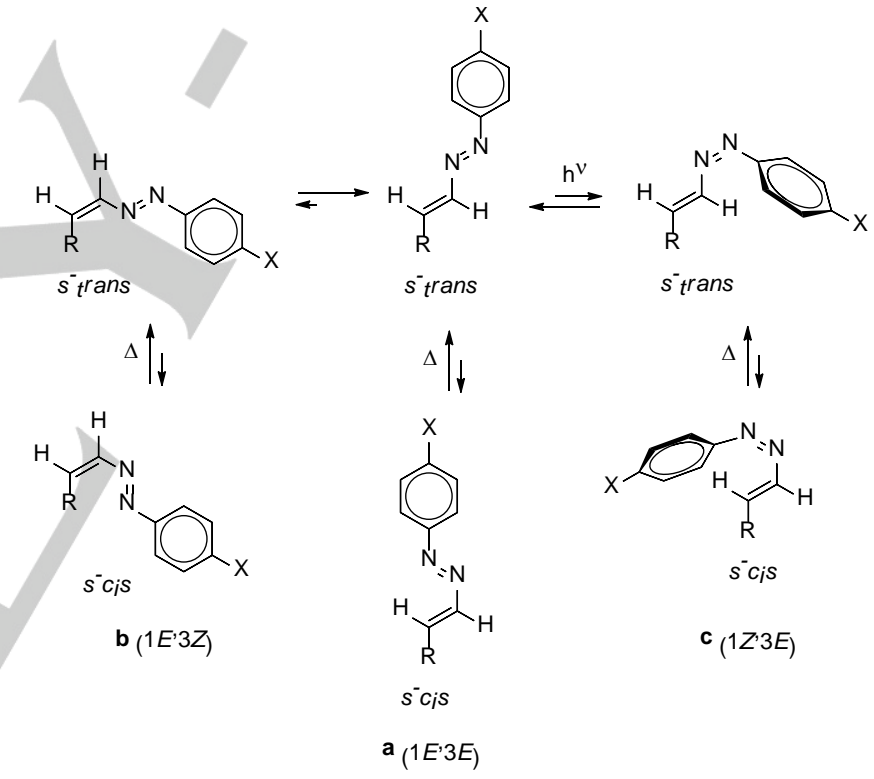

Scheme 6. Dynamic equilibria involving s-trans and s-cis conformations for diazadienes showing different $E$ - and $Z$-configurations.

\section{On the mechanism of azoalkene stereomutation}

\section{The conrotatory ring-closure mechanism}

A mechanistic proposal for the thermal isomerization of azoalkenes was introduced by Schantl and Hebeisen, ${ }^{[16]}$ where $s$-cis conformers arising from both $(1 E, 3 E)$ and $(1 E, 3 Z)$ azoalkenes would lead to trans- and cis-diazocyclobutenes, respectively, by a conrotatory ring-closure. Their interconversion takes place by configurational inversion at the nitrogen atom bearing the aromatic ring. Further conrotatory ring-opening accounts for equilibration between $(1 E, 3 E)$ and $(1 E, 3 Z)$ azoalkenes. An overall picture is shown in Scheme 7 based on azoalkene 11 as simplified model. 


$$
11 \mathrm{a}_{\left(s^{-} \text {trans }^{2}\right.}
$$

${ }_{\mathrm{Ph}}^{N} \prod_{\downarrow}^{\mathrm{TS}_{11 \mathrm{~b}}}$

Scheme 7. Mechanistic proposal applied to the thermal isomerization of azoalkene 11, according to Ref. [16].

Figure 9 and Table 7 collect the relative electronic and free energies of all stationary points involved in the potential energy

hypersurface of $\mathbf{1 1 a} \leftrightarrow \mathbf{1 1 b}$ isomerization. The gas-phase computation shows that, despite the low activation energy $\left(\mathrm{TS}_{15}\right.$ $<4 \mathrm{kcal} / \mathrm{mol}$ ) involving the cis-trans isomerization of diazocyclobutenes 14 and 15, their formation from the corresponding azoalkenes proceeds through high barriers (TS 14 and $\mathrm{TS}_{16}>39 \mathrm{kcal} / \mathrm{mol}$ ), a fact reflecting presumably the strain of the four-membered ring (Figure 10). Related ring closures of substituted 1,3-butadienes to cyclobutenes show similar activation energies (a high energy barrier, $\Delta \mathrm{G}^{\neq} \sim 32 \mathrm{kcal} / \mathrm{mol}$, has been determined for cyclobutene formation). ${ }^{[27]}$ Inclusion of solvent effects $\left(\mathrm{CHCl}_{3}\right.$, benzene, or DMSO) leads to similar results, which are also nearly coincidental with those of gasphase calculations (Table 7). This should otherwise be expected for electrocyclic reactions with an isopolar transition state, which are largely unaffected by solvent variations. ${ }^{[28]}$

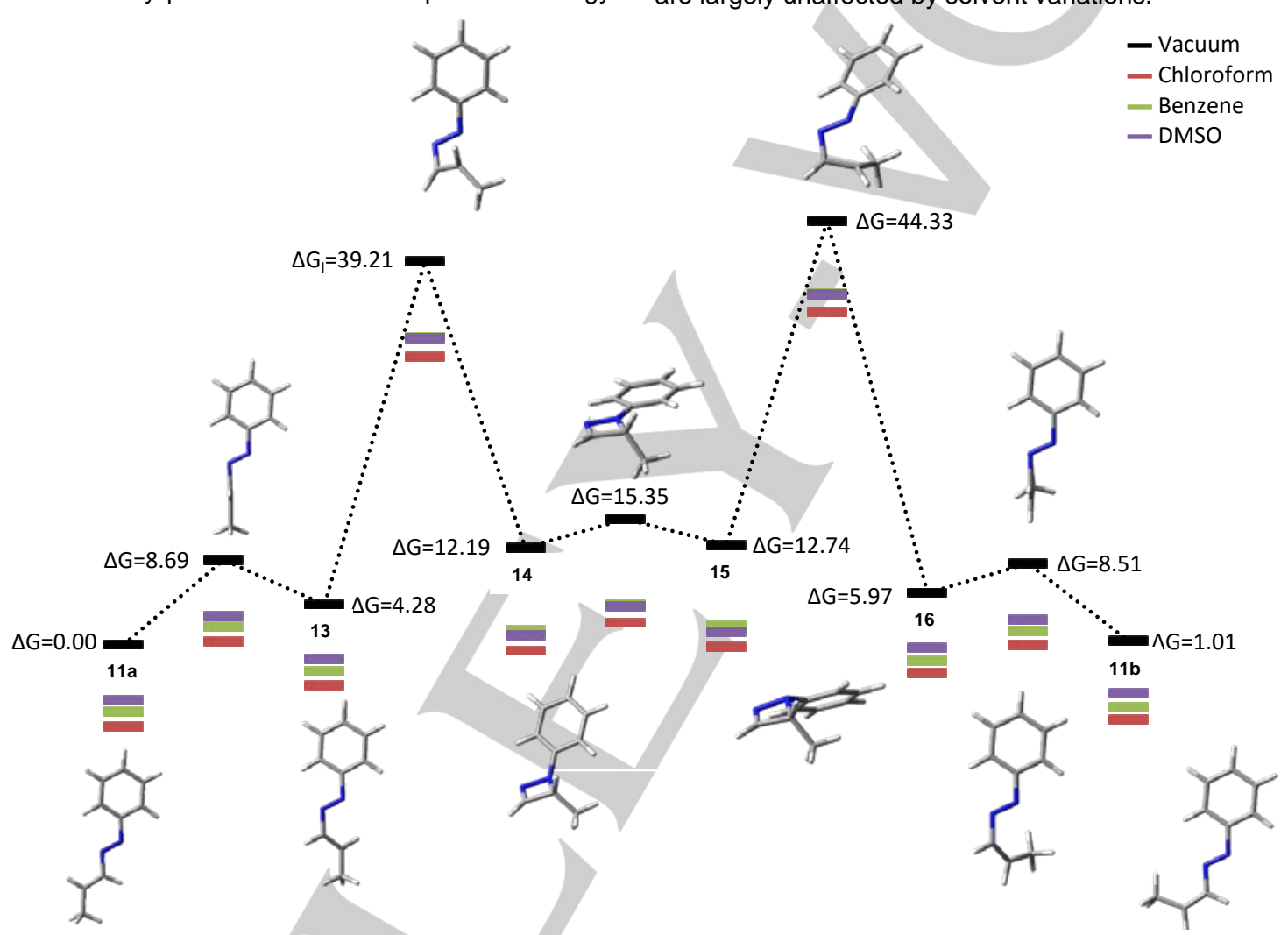

Figure 9. Location of stationary points along the $11 \mathbf{a}(1 E, 3 E)$ to $11 \mathbf{b}(1 E, 3 Z)$ isomerization pathways. Color codes are employed to highlight the energy profile in the gas phase and different solvent systems.

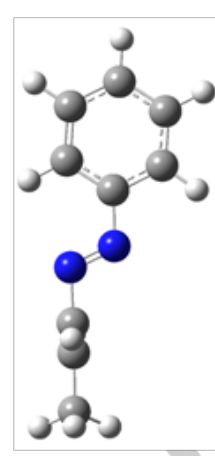

$\mathrm{TS}_{13}$

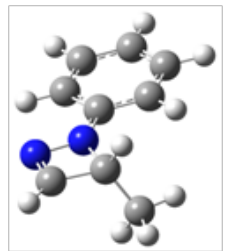

$\mathrm{TS}_{15}$

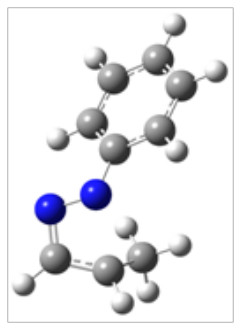

TS $_{16}$

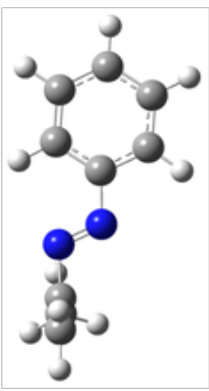

$\mathrm{TS}_{11 \mathrm{~b}}$

Figure 10. Optimized structures for transition states along the 11a $(1 E, 3 E)$ to $11 \mathbf{b}(1 E, 3 Z)$ isomerization path. 
Table 7. Relative stability of stationary states for the $\mathbf{1 1 a / 1 1 b}$ isomerization ${ }^{[a, b]}$

\begin{tabular}{|c|c|c|c|c|c|c|c|c|c|c|c|}
\hline & $11 a$ & $\mathrm{TS}_{13}$ & 13 & $\mathrm{TS}_{14}$ & 14 & $\mathrm{TS}_{15}$ & 15 & $\mathrm{TS}_{16}$ & 16 & $\mathrm{TS}_{11 \mathrm{~b}}$ & $11 b$ \\
\hline$\Delta \mathrm{E}^{[c]}$ & 0.00 & 8.77 & 4.16 & 39.69 & 10.03 & 13.01 & 10.34 & 43.80 & 5.35 & 8.42 & 0.41 \\
\hline$\Delta \mathrm{G}^{[c]}$ & 0.00 & 8.69 & 4.28 & 39.21 & 12.19 & 15.35 & 12.74 & 44.33 & 5.97 & 8.51 & 1.10 \\
\hline$\Delta \mathrm{E}^{[\mathrm{d}]}$ & 0.00 & 8.72 & 4.27 & 38.24 & 7.79 & 10.70 & 8.21 & 42.84 & 5.46 & 8.36 & 0.68 \\
\hline$\Delta \mathrm{G}^{[\mathrm{d}]}$ & 0.00 & 9.57 & 5.32 & 38.88 & 10.60 & 14.08 & 11.53 & 43.82 & 5.17 & 10.23 & 1.92 \\
\hline$\Delta \mathrm{E}^{[\mathrm{e}]}$ & 0.00 & 8.65 & 4.27 & 37.42 & 6.65 & 9.63 & 7.07 & 41.93 & 5.45 & 8.30 & 0.76 \\
\hline$\Delta \mathrm{G}^{[\mathrm{e}]}$ & 0.00 & 8.70 & 4.58 & 37.12 & 8.62 & 12.14 & 9.33 & 42.40 & 6.10 & 7.61 & 1.14 \\
\hline$\Delta \mathrm{E}^{[\mathrm{f}]}$ & 0.00 & 8.79 & 4.22 & 38.77 & 8.50 & 11.15 & 8.91 & 43.25 & 5.32 & 8.37 & 0.53 \\
\hline$\Delta \mathrm{G}^{[\mathrm{f]}}$ & 0.00 & 8.95 & 4.63 & 38.60 & 10.50 & 13.82 & 11.46 & 43.34 & 5.98 & 8.09 & 1.00 \\
\hline
\end{tabular}

[a] $\mathrm{n} \mathrm{kcal/mol.}{ }^{[b]}$ At the M06-2X/6-311G(d,p) level. ${ }^{[c]}$ In the gas phase. ${ }^{[d]}$ Including the solvent effect (SMD model: $\left.\mathrm{CHCl}_{3}\right)$. ${ }^{[\mathrm{e}]}$ Including the solvent effect (SMD model: DMSO). ${ }^{[\mathrm{f}]}$ Including the solvent effect (SMD model: $\left.\mathrm{C}_{6} \mathrm{H}_{6}\right)$.

\section{The acid-catalyzed mechanism}

It is worth noting however that isomerizations of compounds $4 a-$ 9a into $\mathbf{4 b - 9 b}$, respectively, are not observed, at least appreciably, in non-halogenated solvents like benzene, toluene or DMSO. Variable-temperature ${ }^{1} \mathrm{H}$ NMR experiments show that, although an increase in temperature does not produce any change in a solution of $6 a$ in benzene- $d_{6}(\varepsilon=2.3)$, the use of a more polar solvent like DMSO- $d_{6},(\varepsilon=47)$, leads to equilibration with its $\mathbf{6 b}$ isomer (Figures S54-S55). This behavior disagrees with the above-mentioned mechanistic scheme, ${ }^{[16]}$ because of similar energy profiles regardless of the solvent system. On the other hand, the intermediacy of diazetine derivatives has been proposed for azoalkene isomerizations occurring under photochemical or pyrolytic protocols, ${ }^{[29]}$ which deviate from our experimental conditions.
The isomerization is strongly inhibited in $\mathrm{CHCl}_{3}$ after passing this solvent through a column packed with basic alumina, thus removing acid impurities, mainly $\mathrm{HCl}$ (generated by photochemical decomposition). After one week however, equilibration between $(1 E, 3 E)$ and $(1 E, 3 Z)$ isomers of $\mathbf{4}$ and $\mathbf{9}$ is observed again. Clearly, the isomerization should be triggered by such acidic side products. The lack of azoalkene stability in $\mathrm{CHCl}_{3}$ solutions has been sometimes described.[15a,30] Mechanistic hypotheses, compatible with the above facts, could involve either protonation-deprotonation of the azo group thereby enabling facile rotation around the C1-C2 bond, or $[1,4]$ addition of $\mathrm{HCl}$ to the azoalkene moiety, followed by rotation and subsequent [1,4]-elimination, as depicted in Scheme 8 for the interconversion of $\mathbf{4 a / 4} \mathbf{b}$. Similar proposals have been suggested to account for the cis-trans isomerization of diethyl maleate ${ }^{[31]}$ or 3-aryl propenylideniminium salts. ${ }^{[32]}$

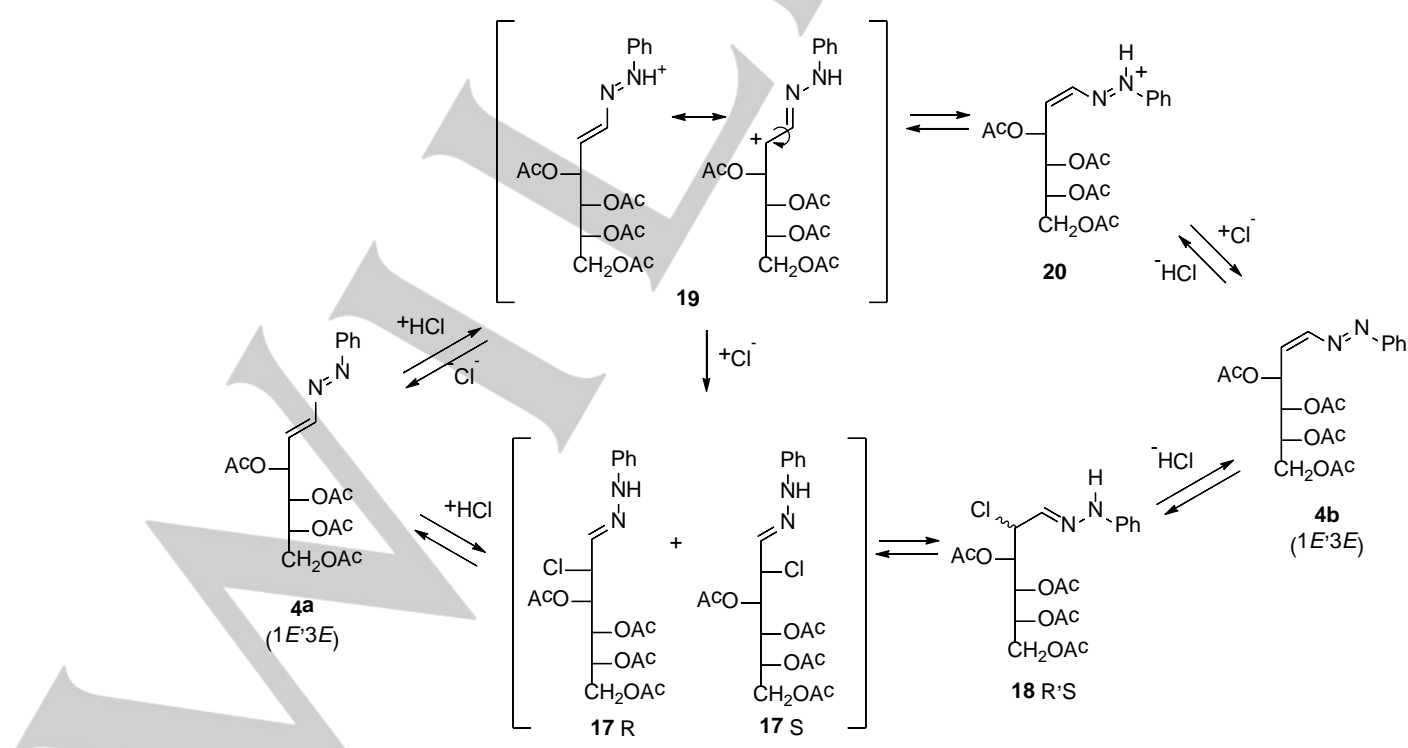

Scheme 8. Mechanistic hypotheses based on stepwise sequences of protonation-deprotonation, bond rotation, [1,4]-addition of HCl/bond rotation, and [1,4]elimination. 
The plausibility of such transformations has now been assessed by theoretical methods and data found for $\mathbf{4 a}$ are shown in Table 8. The specific chirality of the stereoisomeric intermediates $\mathbf{1 7}$ and 18 at the first stereogenic center has been computed too. A mechanism involving addition-elimination of $\mathrm{HCl}$ seems unlikely as the addition products are significantly more stable than the corresponding azoalkenes (Figure 11). The concerted addition of $\mathrm{HCl}$ through the $\mathrm{s}$-cis conformation of 4 a leading to $17(R / S$ mixture) appears to be improbable, because the corresponding transition structures could not be located either.
On the other hand, an alternative protonation mechanism followed by rotation should also be unlikely in the gas phase as it involves polar intermediates and high-energy transition structures $(\Delta \Delta G>110 \mathrm{kcal} / \mathrm{mol})$. Obviously, things may be dramatically different when solvation is taken into account, making it possible the isomerization in $\mathrm{CHCl}_{3}(\Delta \Delta \mathrm{G}<31$ $\mathrm{kcal} / \mathrm{mol})$.

Table $\mathbf{8}$. Relative stability of stationary states for the $\mathbf{4 a} / \mathbf{4 b}$ isomerization ${ }^{[a, b]}$

\begin{tabular}{|c|c|c|c|c|c|c|c|c|}
\hline & $\mathbf{4 a}+\mathrm{HCl}$ & $17 R$ & $17 S$ & $18 R$ & $18 S$ & $19+\mathrm{Cl}^{-}$ & $20+\mathrm{Cl}^{-}$ & $\mathbf{1 b}+\mathrm{HCl}$ \\
\hline$\Delta \mathrm{E}^{[\mathrm{c}]}$ & 0.00 & -23.50 & -23.68 & -19.04 & -24.59 & 106.06 & 116.53 & -2.08 \\
\hline$\Delta \mathrm{G}^{[c]}$ & 0.00 & -7.77 & -7.07 & -4.61 & -7.54 & 113.61 & 121.55 & -2.17 \\
\hline$\Delta \mathrm{E}^{[\mathrm{d}]}$ & 0.00 & -22.50 & -21.65 & -19.47 & -23.37 & 18.88 & 22.64 & -1.32 \\
\hline$\Delta \mathrm{G}^{[\mathrm{d}]}$ & 0.00 & -7.44 & -4.67 & -4.87 & -6.75 & 27.77 & 30.76 & -0.50 \\
\hline
\end{tabular}

${ }^{[a]}$ In kcal/mol. ${ }^{[b]}$ At the M06-2X/6-311G(d,p) level. ${ }^{[c]}$ In the gas phase. ${ }^{[d]}$ Including the solvent effect (SMD model: $\left.\mathrm{CHCl}_{3}\right)$.
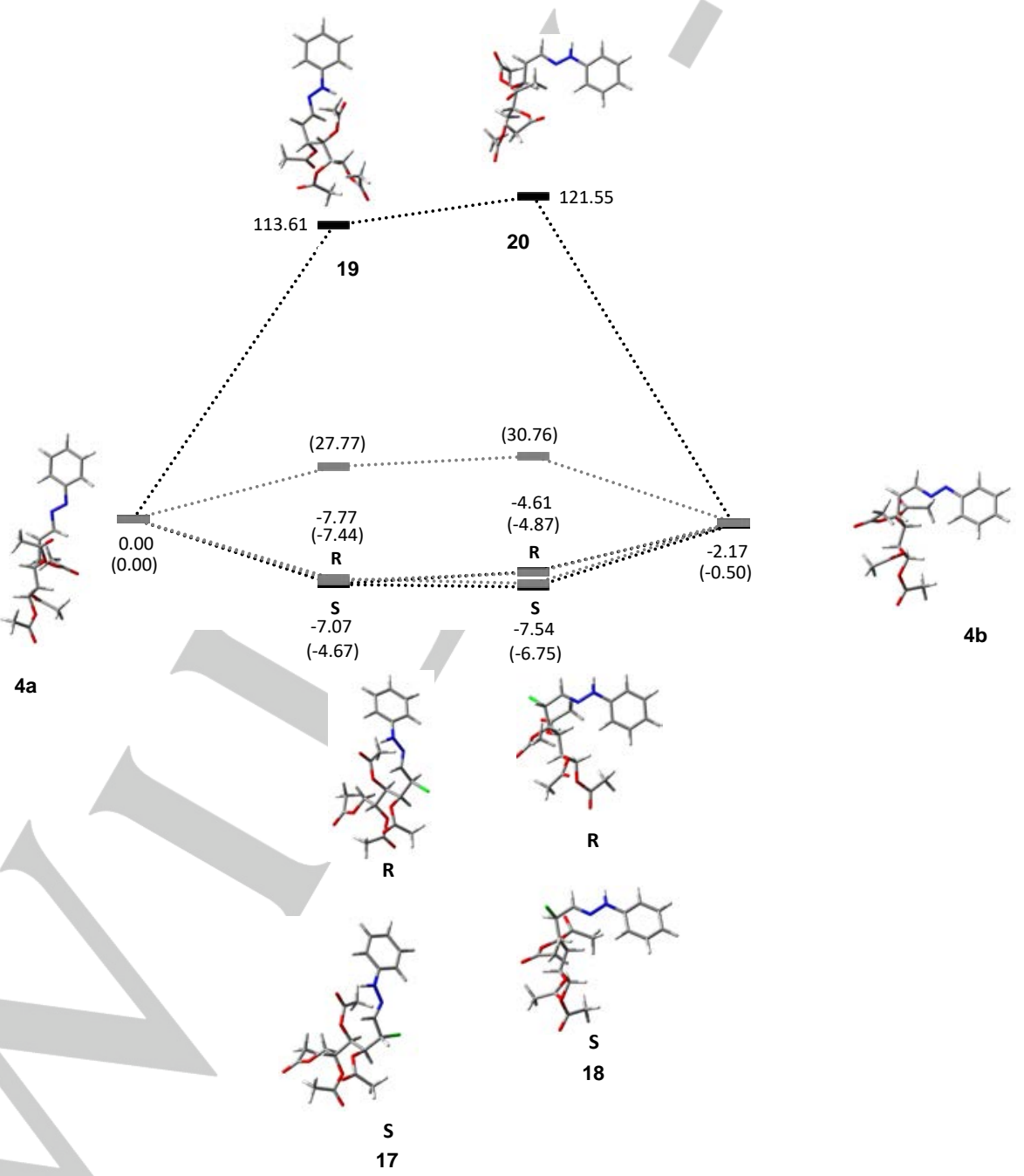

Figure 11. Energy profiles in the gas phase for the different isomerization pathways of $(1 E, 3 E)$ and $(1 E, 3 Z)$-configured azoalkenes (values in parentheses refer to $\mathrm{CHCl}_{3}, \mathrm{SMD}$ model). 
${ }^{1} \mathrm{H}$ NMR monitoring shows that addition of trifluoroacetic acid- $d_{1}$ to a $\mathrm{CDCl}_{3}$ solution of either $\mathbf{4 a}$ or $\mathbf{9 a}$ (ca. $5: 1$ molar ratio, see $\mathrm{SI}$ for details) triggers a fast equilibration between $(1 E, 3 E)$ and $(1 E, 3 Z)$ isomers yielding a ratio coincidental with that obtained in the absence of acid (Figures S56-S58). Fast equilibria are also reached after addition of acetic acid- $d_{4}$ to a solution of $\mathbf{5 a}$ in $\mathrm{CDCl}_{3}$ (5b $\sim 14 \%$ ) or of $\mathrm{D}_{2} \mathrm{SO}_{4}$ (one drop) to a solution of $\mathbf{5 a}$ in DMSO- $d_{6}$. For the latter the isomeric ratio $(5 \mathbf{b} \sim 16 \%)$ is similar to that found in $\mathrm{CDCl}_{3}$. Further addition of acid does not change such equilibria. Equilibration does not occur upon addition of acetic acid- $d_{4}$ to a solution of $\mathbf{5 a}$ in $\mathrm{C}_{6} \mathrm{D}_{6}$, which is however initiated by adding $\mathrm{D}_{2} \mathrm{SO}_{4}(\sim 13 \%$ of the minor isomer).

These observations are more consistent with the protonation mechanism than that of acid addition, as one would expect marked reactivity differences of Brønsted acids in the additionelimination mechanism. In DMSO, acetic acid $\left(\mathrm{pK}_{\mathrm{a}} \sim 12.6\right)^{[33]}$ is weaker than trifluoroacetic acid $\left(\mathrm{pK}_{\mathrm{a}} \sim 0.23\right),{ }^{[34]} \mathrm{HCl}\left(\mathrm{pK}_{\mathrm{a}} \sim\right.$ 1.8), ${ }^{[35]}$ and $\mathrm{H}_{2} \mathrm{SO}_{4}\left(\mathrm{pK}_{\mathrm{a}} \sim 1.99\right)^{[36]}$ with acetate anion being a poorer leaving group than trifluoroacetate, chloride and bisulfate.

One wonders which mechanisms follow the opposite pathway from the photoisomers $(1 Z, 3 E) \mathbf{4 c}-9 \mathbf{c}$ to the starting isomers $(1 E, 3 E) 4 \mathbf{a}-9 \mathbf{a}$. When solutions of the latter in acetone- $d_{6}$ or DMSO- $d_{6}$ are exposed to sunlight, they isomerize to the $(1 Z, 3 E)$ isomers only. With the subsequent addition of trifluoroacetic acid- $d_{1}$, the isomer $(1 Z, 3 E)$ instantly disappears and the $(1 E, 3 Z)$ derivative is formed. These results demonstrate that $1 Z \rightarrow 1 E$ isomerization can occur easily and quickly under acid catalysis. This behavior is illustrated for $\mathbf{6 a}$ in Figures S59-S60 and Scheme 9 shows the plausible mechanism accounting for these transformations.

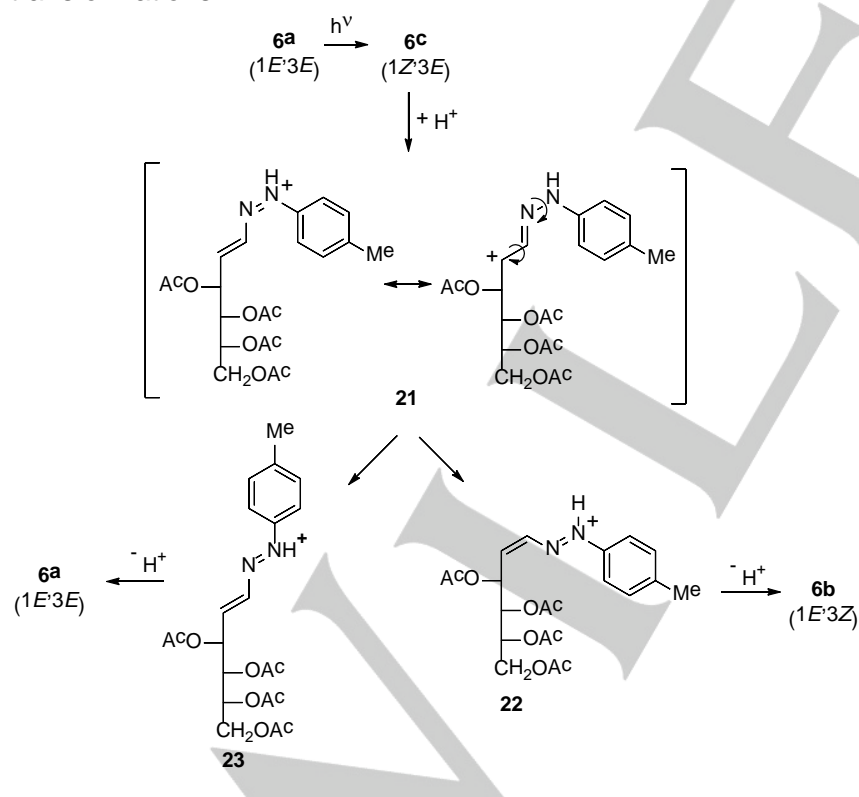

Scheme 9. Mechanistic hypothesis accounting for acid-catalyzed isomerisation of $(1 Z, 3 E)$-azoalkenes.

Thus, azoalkene $\mathbf{6 a}$ is photoisomerized to $\mathbf{6 c}$, which in the presence of acid is protonated (21). The resulting azonium ion easily isomerizes via rotation since protonation produces a decrease in the double bond character, not only between the carbon atoms of the $\mathrm{C}=\mathrm{C}$ bond but also between the nitrogen atoms of the azo linkage, ${ }^{[37]}$ thereby enabling their rotations (22 and 23). Given the fact that stereoisomers $(1 Z, 3 E)$ are $\sim 10-12$ $\mathrm{kcal} \mathrm{mol}^{-1}$ less stable than those with stereochemistry $(1 E, 3 E)$ and $(1 E, 3 Z)$ (see Table 5), only the latter could be detected as minor component in the final equilibrium mixture.

These results can be exploited to inhibit the photoisomerization of azoalkenes in the presence of an appropriate acid. In fact, when a solution of $\mathbf{6 a}$ in DMSO- $d_{6}$, to which trifluoroacetic acid$d_{1}$ had been previously added, was irradiated, only the $(1 E, 3 Z)$ isomer (6b) was detected (Figure 61S).

Moreover, such experimental findings allow us to conclude that under photochemical conditions and in the absence of acids, only the $1 E \rightarrow 1 Z$ isomerization takes place, whereas the presence of acids leads exclusively to $3 E \rightarrow 3 Z$ isomerization. Notably, under no circumstances will both isomerizations be occurring at the same time. We have found no data supporting the presence of the $(1 Z, 3 Z)$ isomers, as their formation should actually be difficult. The generation of such an isomer from its $(1 E, 3 E)$ counterpart is not feasible, because both photochemical isomerization plus acid catalysis acting simultaneously or sequentially would be required.

When solutions of compounds 4-9 were left to stand in $\mathrm{CHCl}_{3}$ solutions for several days, progressive browning was observed, indicative of azoalkene degradation as inferred from TLC analyses and NMR spectra.

\section{Conclusions}

The preceding results show for the first time the fate of chiral azoalkenes derived from acyclic sugars, which undergo double bond isomerizations. Both the structure and conformational profile of such species in solution can be determined with confidence through diagnostic spectroscopic signals and computational analysis. Visible-light irradiation of $1 E$-configured azoalkenes causes their isomerization into $1 Z$-isomers, while the opposite $1 Z \rightarrow 1 E$ isomerization occurs thermally in the dark or under acid catalysis. The mechanism of thermal stereomutation has been investigated thoroughly by experimental and theoretical methods. While a conrotatory ring-closure mechanism, once proposed for simpler derivatives, should be ruled out, acid-catalyzed transformations represent the most plausible scenarios. However, protonation rather than additionelimination pathways, appears to be consistent with our experimental findings. Thus, the $3 E \rightarrow 3 Z$ and $1 Z \rightarrow 1 E$ isomerizations proceeds in chloroform solution and in the presence of acids.

\section{Experimental Section}

\section{Computational analyses}

Cartesian coordinates for all computed species have been included in the Supporting material. The DFT study has been conducted using the M06-2X hybrid density functional[20] in conjuction with the $6-311 G(d, p)$ basis set ${ }^{[21]}$ as implemented in the Gaussian09 package. ${ }^{[22]}$ The M06-2X functional was chosen 
on the basis of previous studies showing its accuracy in determining conformational energies of non-covalent interactions. ${ }^{[38]}$ Frequency analysis were performed to confirm the existence of true minima on the potential energy surface. All thermal corrections were calculated at the standard values of 1 atm at $298.15 \mathrm{~K}$. Solvent effects were estimated by the continuum solvation model, based on the quantum mechanical charge density (SMD), and comprising the bulk electrostatic contribution from a self-consistent reaction field treatment, plus a second contribution from short-range solute-solvent interactions in the first solvation cell (cavity-dispersion-solvent-structure term) that takes into account different contribution such as longrange electrostatic polarization (bulk solvent effects). ${ }^{[23,39]}$

\section{Spectroscopic methods}

Crystallographic data (acquisition method, refinement, and structural parameters) as well as spectroscopic monitoring of sugar azoalkenes in solution are collected in the Supporting information. FT-IR and Raman spectra were recorded in the range of $4000-600 \mathrm{~cm}^{-1}$ using $\mathrm{KBr}$ (Merck) pellets on a Thermo spectrophotometer and a Nicolet Almega XR (Thermo scientific) apparatus, respectively. NMR spectra were recorded on a Bruker instrument operating at 400 and $500 \mathrm{MHz}$ for ${ }^{1} \mathrm{H}$, and 100 and $125 \mathrm{MHz}$ for ${ }^{13} \mathrm{C}$ nuclei, respectively. Hydrogen and carbon atom assignments were facilitated by DEPT (Distortionless Enhancement by Polarization Transfer), COSY (Correlation Spectroscopy) and HMQC (Heteronuclear Multiple-Quantum Correlation) experiments and isotopic exchange after addition of $\mathrm{D}_{2} \mathrm{O}$ for proton resonances.

NMR studies on the Isomerization of (1E,3E)-1,2-diaza-1,3butadienes (4a-9a) into (1E,3Z)-1,2-diaza-1,3-butadienes (4b9b). All samples were prepared by dissolving $(1 E, 3 E)$ azoalkenes $(0.1 \mathrm{~g})$ in $\mathrm{CDCl}_{3}(0.5 \mathrm{~mL})$. Their evolution was monitored by ${ }^{1} \mathrm{H}$ NMR spectroscopy for $36 \mathrm{~h}$. Formation of the corresponding $(1 E, 3 Z)$ isomers (ca. 5:1) could be observed; structural assignment and peak identification of each isomer were performed as follows:

Mixture of Compounds (1E,3E)-4-(tetra-O-acetyl-D-arabinotetritol-1-yl)-1-phenyl-1,2-diaza-1,3-butadiene (4a) and (1E,3Z)-4-(tetra-O-acetyl-D-arabino-tetritol-1-yl)-1-phenyl-1,2diaza-1,3-butadiene (4b): $E / Z$ ratio after equilibration (\%) = 82:18. ${ }^{1} \mathrm{H}$ NMR $\left(500 \mathrm{MHz}, \mathrm{CDCl}_{3}\right) \delta 7.84-7.82(\mathrm{~m}, 2 \mathrm{H}, \mathbf{Z}), 7.78-$ $7.76(\mathrm{~m}, 2 \mathrm{H}, \boldsymbol{E}), 7.50-7.45(\mathrm{~m}, 3 \mathrm{H}, \boldsymbol{E}+\boldsymbol{Z}), 7.33(\mathrm{dd}, \mathrm{J}=13.5, \mathrm{~J}=$ $1.2 \mathrm{~Hz}, 1 \mathrm{H}, E), 7.21$ (dd, J=7.7, J=0.9 Hz, 1H, Z), 6.89 (ddd, J $=8.1, J=4.6, J=0.8 \mathrm{~Hz}, 1 \mathrm{H}, Z), 6.78(\mathrm{dd}, \mathrm{J}=13.6, \mathrm{~J}=5.8 \mathrm{~Hz}$, $1 \mathrm{H}, E), 6.10$ (t, J=8.0 Hz, 1H, Z), 5.94 (ddd, $\mathrm{J}=5.8, \mathrm{~J}=3.2, \mathrm{~J}=$ $1.2 \mathrm{~Hz}, 1 \mathrm{H}, \boldsymbol{E}), 5.55(\mathrm{~m}, 1 \mathrm{H}, \boldsymbol{Z}), 5.53(\mathrm{dd}, \mathrm{J}=8.4, \mathrm{~J}=3.4 \mathrm{~Hz}$, $1 \mathrm{H}, E$ ), 5.29 (ddd, $\mathrm{J}=8.0, \mathrm{~J}=4.8, \mathrm{~J}=2.7 \mathrm{~Hz}, 1 \mathrm{H}, E), 5.29(\mathrm{~m}$, $1 \mathrm{H}, Z$ ), 4.31 (dd, $\mathrm{J}=12.4, \mathrm{~J}=2.8 \mathrm{~Hz}, 1 \mathrm{H}, Z$ ), 4.30 (dd, $\mathrm{J}=12.5$, $J=2.6 \mathrm{~Hz}, 1 \mathrm{H}, E), 4.23(\mathrm{dd}, \mathrm{J}=12.1, \mathrm{~J}=4,6 \mathrm{~Hz}, 1 \mathrm{H}, \mathrm{Z}), 4.21$ (dd, $J=12.6, J=4.6 \mathrm{~Hz}, 1 \mathrm{H}, E), 2.15(\mathrm{~s}, 3 \mathrm{H}, E), 2.10$ (s, 3H, E), 2.08 (s, 3H, E), 1.94 (s, 3H, Z); ${ }^{13} \mathrm{C}$ NMR (125 MHz, $\left.\mathrm{CDCl}_{3}\right) \delta$ $170.6(E+Z), 169.8(E+Z), 169.7(E+Z), 169.6(E+Z), 152.6(Z)$, $152.3(E), 150.0(E), 147.6(Z), 136.5(E), 131.9(Z), 131.7(Z)$, $131.4(E), 129.1(E+Z), 123.2(Z), 122.9(E), 71.7(Z), 70.0(E)$, $69.3(E), 69.0(Z), 68.3(E), 67.4(Z), 61.8(E+Z), 20.8(E+Z)$, $20.7(E+Z), 20.6(E+Z), 20.4(E+Z)$.
Mixture of Compounds (1E,3E)-4-(tetra-O-acetyl-D-arabinotetritol-1-yl)-1-(4-methoxyphenyl)-1,2-diaza-1,3-butadiene (5a) and (1E,3Z)-4-(tetra-O-acetyl-D-arabino-tetritol-1-yl)-1(4-methoxyphenyl)-1,2-diaza-1,3-butadiene (5b): $E / Z$ ratio after equilibration $(\%)=81: 19 .{ }^{1} \mathrm{H} \mathrm{NMR}\left(500 \mathrm{MHz}, \mathrm{CDCl}_{3}\right) \delta 7.80$ $(\mathrm{d}, J=8.8 \mathrm{~Hz}, 2 \mathrm{H}, Z), 7.76(\mathrm{~d}, J=9.8 \mathrm{~Hz}, 2 \mathrm{H}, E), 7.29$ (dd, $J=$ 13.5, $J=1.2 \mathrm{~Hz}, 1 \mathrm{H}, E), 7.14(\mathrm{dd}, J=7.7, J=1.0 \mathrm{~Hz}, 1 \mathrm{H}, Z)$, 6.98-6.89 (m, 2H E+2H Z), 6.869 (ddd, $\mathrm{J}=8.1, \mathrm{~J}=4.6, \mathrm{~J}=0.8$ $\mathrm{Hz}, 1 \mathrm{H}, Z), 6.65$ (dd, J = 13.6, J = 6.2 Hz, 1H, E), $5.98(\mathrm{t}, J=8.1$ $\mathrm{Hz}, 1 \mathrm{H}, Z$ ), 5. 89 (ddd, $\mathrm{J}=6.0, \mathrm{~J}=3.4, \mathrm{~J}=1.2 \mathrm{~Hz}, 1 \mathrm{H}, E$ ), 5.52 (m, $1 \mathrm{H}, \boldsymbol{Z}$ ), 5.50 (dd, $\mathrm{J}=8.3, \mathrm{~J}=3.5 \mathrm{~Hz}, 1 \mathrm{H}, E), 5.27$ (ddd, $\mathrm{J}=$ $7.6, J=4.4, J=2.7 \mathrm{~Hz}, 1 \mathrm{H}, E), 5.27(\mathrm{~m}, 1 \mathrm{H}, \mathrm{Z}), 4.31(\mathrm{~m}, 1 \mathrm{H}, \mathrm{Z})$, $4.29(\mathrm{dd}, J=12.4, J=2.6 \mathrm{~Hz}, 1 \mathrm{H}, E), 4.21(\mathrm{~m}, 1 \mathrm{H}, Z), 4.20$ (dd, $J=12.6, J=5.0 \mathrm{~Hz}, 1 \mathrm{H}, E), 3.87(\mathrm{~s}, 3 \mathrm{H}, Z), 3.85(\mathrm{~s}, 3 \mathrm{H}, E), 2.11$ (s, 3H, E), 2.08 (s, 3H, E), 2.05 (s, 3H, E), 1.94 (s, 3H, Z); ${ }^{13} \mathrm{C}$ NMR $\left(125 \mathrm{MHz}, \mathrm{CDCl}_{3}\right) \delta 170.4,169.7,169.6,169.5,169.4$, $162.5,162.3,150.1,147.6,147.0,146.6,134.1,129.8,125.0$, $124.7,114.1,71.7,70.0,69.3,69.0,68.3,67.3,61.8,61.7,55.4$, $20.8,20.6,20.5,20.5$.

Mixture of Compounds (1E,3E)-4-(tetra-O-acetyl-D-arabinotetritol-1-yl)-1-(4-methylphenyl)-1,2-diaza-1,3-butadiene (6a) and (1E,3Z)-4-(tetra-O-acetyl-D-arabino-tetritol-1-yl)-1-(4methoxyphenyl)-1,2-diaza-1,3-butadiene (6b): $E / Z$ ratio after equilibration (\%) $=86: 14 .{ }^{1} \mathrm{H}$ NMR $\left(500 \mathrm{MHz}, \mathrm{CDCl}_{3}\right) \delta 7.72(\mathrm{~d}, \mathrm{~J}$ $=8.3 \mathrm{~Hz}, 2 \mathrm{H}, \mathrm{Z}), 7.59(\mathrm{~d}, \mathrm{~J}=8.3 \mathrm{~Hz}, 2 \mathrm{H}, E), 7.23(\mathrm{dd}, \mathrm{J}=13.6, \mathrm{~J}$ $=1.2 \mathrm{~Hz}, 1 \mathrm{H}, E), 7.17(\mathrm{~d}, J=8.1 \mathrm{~Hz}, 2 \mathrm{H} \mathrm{E}+2 \mathrm{H} \mathrm{Z}), 7.10$ (d, J = $7.9,1 \mathrm{H}, Z$ ), 6.87 (ddd, J = 8.4, J = 4.8 Hz, J=1.0 Hz, $1 \mathrm{H}, Z$ ), $6.65(\mathrm{dd}, \mathrm{J}=13.6, \mathrm{~J}=6.0 \mathrm{~Hz}, 1 \mathrm{H}, E), 6.04(\mathrm{t}, \mathrm{J}=8.1 \mathrm{~Hz}, 1 \mathrm{H}, Z)$, 5.84 (ddd, $J=6.0, J=3.3, J=1.0 \mathrm{~Hz}, 1 \mathrm{H}, E), 5.53$ (dd, $J=8.1$, $J=4.8,1 \mathrm{H}, Z$ ), 5.44 (dd, $J=8.5, J=3.2,1 \mathrm{H}, E), 5.21$ (ddd, $J=$ $8.0, J=4.8, J=2.7 \mathrm{~Hz}, 1 \mathrm{H}, E), 5.21(\mathrm{~m}, 1 \mathrm{H}, Z), 4.31$ (dd, $\mathrm{J}=$ $12.3, J=2.6 \mathrm{~Hz}, 1 \mathrm{H}, Z), 4.21(\mathrm{dd}, J=12.5, J=2.7 \mathrm{~Hz}, 1 \mathrm{H}, E)$, 4.14 (m, 1H, Z), 4.12 (dd, J = 12.5, J = 4.9 Hz, 1H, E), 2.42 (s, $3 \mathrm{H}, Z$ ), 2.31 (s, 3H, E), 2.06 (s, 3H, E), 2,01 (s, 3H, E), 2,00 (s, $3 \mathrm{H}, \boldsymbol{E}), 1.85(\mathrm{~s}, 3 \mathrm{H}, \boldsymbol{Z}) ;{ }^{13} \mathrm{C}$ NMR $\left(125 \mathrm{MHz}, \mathrm{CDCl}_{3}\right) \delta 170.4$, $169.7,169.6,169.5,169.4,162.5,150.7,150.3,150.0,147.6$, $142.3,142.0,135.4,131.0,129.6,123.1,122.8,71.7,70.0,69.3$, 69.0, 68.3, 67.3, 61.8, 61.7, 21.3, 20.8, 20.7, 20.6, 20.5.

Mixture of Compounds (1E,3E)-4-(tetra-O-acetyl-D-arabinotetritol-1-yl)-1-(4-chlorophenyl)-1,2-diaza-1,3-butadiene (7a) and (1E,3Z)-4-(tetra-O-acetyl-D-arabino-tetritol-1-yl)-1-(4chlorophenyl)-1,2-diaza-1,3-butadiene (7b): $E / Z$ ratio after equilibration (\%) = 88:12. ${ }^{1} \mathrm{H}$ NMR $\left(500 \mathrm{MHz}, \mathrm{CDCl}_{3}\right) \delta 7.76(\mathrm{~d}, \mathrm{~J}$ $=8.7, \mathrm{~Hz}, 2 \mathrm{H}, Z), 7.63(\mathrm{~m}, 2 \mathrm{H}, \boldsymbol{E}), 7.49-7.43(\mathrm{~m}, 2 \mathrm{H} \mathrm{E}+2 \mathrm{H} \mathrm{Z})$, $7.24(\mathrm{dd}, \mathrm{J}=13.5, \mathrm{~J}=1.6 \mathrm{~Hz}, 1 \mathrm{H} \mathrm{E}), 7.18(\mathrm{dd}, \mathrm{J}=7.6, \mathrm{~J}=1.2$ $\mathrm{Hz}, 1 \mathrm{H}, Z$ ), 6.85 (ddd, $\mathrm{J}=9.6, \mathrm{~J}=5.2 \mathrm{~Hz}, \mathrm{~J}=1.2 \mathrm{~Hz}, 1 \mathrm{H}, Z$ ), $6.71(\mathrm{dd}, J=13.5, J=5.9 \mathrm{~Hz}, 1 \mathrm{H}, E), 6.11(\mathrm{t}, J=8.4 \mathrm{~Hz}, 1 \mathrm{H}, Z)$, 5.85 (ddd, $J=5.5, J=3.1, J=1.3 \mathrm{~Hz}, 1 \mathrm{H}, E), 5.52(\mathrm{~m}, 1 \mathrm{H}, Z$ ), 5.45 (dd, $J=8.5, J=3,3,1 \mathrm{H}, E), 5.21$ (ddd, $J=8,0, J=4.7, J=$ $2.8 \mathrm{~Hz}, 1 \mathrm{H}, E), 5.31(\mathrm{~m}, 1 \mathrm{H}, \mathrm{Z}), 4.23(\mathrm{dd}, J=12.3, \mathrm{~J}=2.9 \mathrm{~Hz}$, $1 \mathrm{H}, Z$ ), 4.22 (dd, $\mathrm{J}=12.5, \mathrm{~J}=2.8 \mathrm{~Hz}, 1 \mathrm{H}, E), 4.14(\mathrm{~m}, 1 \mathrm{H}, Z$ ), 4.13 (dd, $J=12.5, J=4.9 \mathrm{~Hz}, 1 \mathrm{H}, E), 2.07$ (s, 3H, E), 2.03 (s, $3 \mathrm{H}, E), 2.01(\mathrm{~s}, 3 \mathrm{H}, E), 1.89(\mathrm{~s}, 3 \mathrm{H}, \mathrm{Z}) ;{ }^{13} \mathrm{C}$ NMR (125 MHz, $\left.\mathrm{CDCl}_{3}\right) \delta 170.4,169.8,169.7,169.6,169.5,150.9,150.6,149.8$, $147.4,137.6,137.2,137.0,132.3,129.3,129.2,124.3,124.0$, $71.6,69.9,69.2,68.9,68.3,67.3,61.7,20.7,20.6,20.5$. 
Mixture of Compounds (1E,3E)-4-(tetra-O-acetyl-D-arabinotetritol-1-yl)-1-(4-bromophenyl)-1,2-diaza-1,3-butadiene (8a) and $\quad(1 E, 3 Z)-4-(t e t r a-O-a c e t y l-D-a r a b i n o-t e t r i t o l-1-y l)-1-(4-$ bromophenyl)-1,2-diaza-1,3-butadiene (8b): $E / Z$ ratio after equilibration (\%) = 92:8. ${ }^{1} \mathrm{H}$ NMR $\left(500 \mathrm{MHz}, \mathrm{CDCl}_{3}\right) \delta 7.63(\mathrm{~d}, \mathrm{~J}$ $=8.6 \mathrm{~Hz}, 2 \mathrm{H}, \mathrm{Z}), 7.57(\mathrm{~d}, \mathrm{~J}=8.8 \mathrm{~Hz}, 2 \mathrm{H}, \mathrm{Z}), 7.57(\mathrm{~d}, \mathrm{~J}=8.8 \mathrm{~Hz}$, $2 \mathrm{H}, E), 7.52(\mathrm{~d}, J=8.8 \mathrm{~Hz}, 2 \mathrm{H}, E), 7.24(\mathrm{dd}, J=13.5, \mathrm{~J}=1.1$ $\mathrm{Hz}, 1 \mathrm{H}, E$ ), 7.18 (dd, $\mathrm{J}=7.6, \mathrm{~J}=1.2 \mathrm{~Hz}, 1 \mathrm{H}, \mathrm{Z}$ ), 6.85 (ddd, $\mathrm{J}=$ $9.2, J=5.0 \mathrm{~Hz}, \mathrm{~J}=1.2 \mathrm{~Hz}, 1 \mathrm{H}, Z), 6.72(\mathrm{dd}, J=13.5, J=4.9 \mathrm{~Hz}$, $1 \mathrm{H}, E), 6.12$ (t, $J=8.2 \mathrm{~Hz}, 1 \mathrm{H}, Z$ ), 5.85 (ddd, $J=4.9, J=2.8, J=$ $1.1 \mathrm{~Hz}, 1 \mathrm{H}, E$ ), 5.84 (dd, J =7.5 Hz, J=4.0 Hz, 1H, Z), 5.41 (dd, $J=8.5, J=3.2,1 \mathrm{H}, E), 5.21$ (ddd, $J=7.9, J=4.7, J=2.7 \mathrm{~Hz}$, $1 \mathrm{H}, E), 5.39$ (dd, $J=12.5 \mathrm{~Hz}, J=3.0 \mathrm{~Hz}, 1 \mathrm{H}, \mathrm{Z}), 4.32$ (dd, $\mathrm{J}=$ $12.5, J=5.5 \mathrm{~Hz}, 1 \mathrm{H}, Z), 4.23(\mathrm{dd}, J=12.5, J=2.7 \mathrm{~Hz}, 1 \mathrm{H}, E)$, $4.13(\mathrm{dd}, J=12.5, \mathrm{~J}=4.8 \mathrm{~Hz}, 1 \mathrm{H}, E), 4.13(\mathrm{~m}, 1 \mathrm{H}, Z), 2.07$ (s, 3H, E), 2.03 (s, 3H, E), 2.00 (s, 3H, E), $1.89(\mathrm{~s}, 3 \mathrm{H}, \mathrm{Z}) ;{ }^{13} \mathrm{C}$ NMR $\left(125 \mathrm{MHz}, \mathrm{CDCl}_{3}\right) \delta 170.4,169.8,169.7,169.5,151.3,150.9$, $149.8,147.4,137.1,132.6,132.4,132.3,132.2,131.9,129.0$, $126.2,125.8,124.5,124.3,123.2,71.6,69.9,69.2,68.9,68.3$, $67.3,61.8,61.7,20.8,20.7,20.6,20.5$

Mixture of Compounds (1E,3E)-4-(tetra-O-acetyl-D-lyxotetritol-1-yl)-1-phenyl-1,2-diaza-1,3-butadiene (9a) and (1E,3Z)-4-(tetra-O-acetyl-D-lyxo-tetritol-1-yl)-1-phenyl-1,2diaza-1,3-butadiene (9b): $E / Z$ ratio after equilibration (\%) = 84:16. ${ }^{1} \mathrm{H} \mathrm{NMR}\left(500 \mathrm{MHz}, \mathrm{CDCl}_{3}\right) \delta 7.85(\mathrm{~d}, \mathrm{~J}=8.0 \mathrm{~Hz}, 2 \mathrm{H}, \boldsymbol{Z})$, $7.78(\mathrm{~m}, 2 \mathrm{H}, \boldsymbol{E}), 7.49-7.46(\mathrm{~m}, 3 \mathrm{H} \mathrm{E}+3 \mathrm{H} \mathrm{Z}), 7.38(\mathrm{~d}, \mathrm{~J}=13.4 \mathrm{~Hz}$, $1 \mathrm{H}, E), 7.25$ (dd, $J=8.2 \mathrm{~Hz}, J=1.0 \mathrm{~Hz}, 1 \mathrm{H}, Z$ ), 6.82 (ddd, $J=$ $9.0 \mathrm{~Hz}, J=6.0 \mathrm{~Hz}, \mathrm{~J}=1.0 \mathrm{~Hz}, 1 \mathrm{H}, Z), 6.78$ (dd, $\mathrm{J}=13.7, \mathrm{~J}=7.8$ $\mathrm{Hz}, 1 \mathrm{H}, E), 6.18$ (dd, J = 9.0 Hz, J = 8.2 Hz, 1H, Z), $5.72(\mathrm{t}, \mathrm{J}=$ $7.2 \mathrm{~Hz}, 1 \mathrm{H}, E), 5.56(\mathrm{dd}, \mathrm{J}=6.0, \mathrm{~J}=4.5 \mathrm{~Hz}, 1 \mathrm{H}, Z$ ), 5.50-5.47 $(\mathrm{m}, 2 \mathrm{H}, E), 5.41$ (ddd, $\mathrm{J}=6.5, \mathrm{~J}=5.0 \mathrm{~Hz}, \mathrm{~J}=4.5 \mathrm{~Hz}, 1 \mathrm{H}, \mathrm{Z}$ ), 4.29 (dd, $J=11.8, J=5.0 \mathrm{~Hz}, 1 \mathrm{H}, E), 4.23(\mathrm{dd}, \mathrm{J}=11.5, \mathrm{~J}=5.0$ $\mathrm{Hz}, 1 \mathrm{H}, \mathrm{Z}$ ), 4.13 (dd, $\mathrm{J}=11.5, \mathrm{~J}=6.5 \mathrm{~Hz}, 1 \mathrm{H}, \mathrm{Z}$ ), 4.04 (dd, $\mathrm{J}=$ $11.9, \mathrm{~J}=6.2 \mathrm{~Hz}, 1 \mathrm{H}, E), 2.11(\mathrm{~s}, 3 \mathrm{H}, E), 2.10(\mathrm{~s}, 3 \mathrm{H}, \boldsymbol{E}), 2.09$ (s, 3H, E), 2.08 (s, 3H, Z), 2.07 (s, 3H, E), 2.04 (s, 3H, Z), 2.02 (s, $3 \mathrm{H}, \boldsymbol{Z}) ;{ }^{13} \mathrm{C}$ NMR $\left(125 \mathrm{MHz}, \mathrm{CDCl}_{3}\right) \delta 170.4(\boldsymbol{E}), 170.0(\boldsymbol{E}), 169.9$ (Z), 169.8 (Z), $169.4(Z), 152.5(Z), 152.3(E), 151.2(E), 148.4$ (Z), $135.8(E), 131.8(Z), 131.5(E), 129.1(E+Z), 123.3(Z)$, $122.9(E), 70.8(E+Z), 69.1(E), 68.5(Z), 68.1(E), 67.1(Z), 61.9$ (Z), $61.8(E), 20.9(E+Z), 20.8(E+Z), 20.7(E+Z)$.

Photoisomerization of (1E,3E)-1,2-diaza-1,3-butadienes (4a9a) into (1Z,3E)-1,2-diaza-1,3-butadienes (4c-9c): All samples were prepared by dissolving $(1 E, 3 E)$-azoalkenes $(0.1 \mathrm{~g})$ in benzene $(0.5 \mathrm{~mL})$. Their evolution was monitored by ${ }^{1} \mathrm{H}$ NMR spectroscopy after $1 \mathrm{~h}$ of irradiation with sunlight. Formation of the corresponding $(1 Z, 3 E)$ isomers could be observed; structural assignment and peak identification of each isomer were performed as follows:

Mixture of Compounds (1E,3E)-4-(tetra-O-acetyl-D-arabinotetritol-1-yl)-1-phenyl-1,2-diaza-1,3-butadiene (4a) and (1Z,3E)-4-(tetra-O-acetyl-D-arabino-tetritol-1-yl)-1-phenyl-1,2diaza-1,3-butadiene (4c): $E / Z$ ratio after equilibration (\%) = 90:10. ${ }^{1} \mathrm{H}$ NMR $\left(500 \mathrm{MHz}, \mathrm{C}_{6} \mathrm{D}_{6}\right) \delta 7.86(\mathrm{~m}, 2 \mathrm{H}$, arom, E), 7.60 $(\mathrm{dd}, J(1,2)=13.5, J(1,3)=1.5 \mathrm{~Hz}, 1 \mathrm{H}, \mathrm{H}-1, E), 7.23(\mathrm{dd}, J(1,2)=$ $13.5, J(1,3)=1.5 \mathrm{~Hz}, 1 \mathrm{H}, \mathrm{H}-1, Z), 7.08(\mathrm{~m}, 2 \mathrm{H}$, arom, $E), 7.03$ $(\mathrm{m}, 1 \mathrm{H}, \boldsymbol{E}), 6.95(\mathrm{~m}, 2 \mathrm{H}$, arom, Z), $6.93(\mathrm{dd}, J(1,2)=13.5, J(1,3)$ $=6.0 \mathrm{~Hz}, 1 \mathrm{H}, \mathrm{H}-2, \mathrm{Z}), 6.88(\mathrm{dd}, J(1,2)=13.5, J(1,3)=5.5 \mathrm{~Hz}$, $1 \mathrm{H}, \mathrm{H}-2, E), 6.81(\mathrm{~m}, 1 \mathrm{H}$, arom, Z), $6.68(\mathrm{~m}, 1 \mathrm{H}$, arom, $Z), 6.04$
$($ ddd, $J(2,3)=5.5, J(3,4)=3.0, J(1,3)=1.5 \mathrm{~Hz}, 1 \mathrm{H}, \mathrm{H}-3, E), 5.74$ (ddd, $J(2,3)=6.0, J(3,4)=3.0, J(1,3)=1.5 \mathrm{~Hz}, 1 \mathrm{H}, \mathrm{H}-3, Z$ ), 5.62 $(\mathrm{dd}, J(4,5)=9.0, J(3,4)=3.0 \mathrm{~Hz}, 1 \mathrm{H}, \mathrm{H}-4, E), 5.50(\mathrm{dd}, J(4,5)=$ 8.5, J(3,4) = 3.0 Hz, 1H, H-4, Z), $5.46\left(\mathrm{ddd}, J(4,5)=9.0, J\left(5,6^{\prime}\right)=\right.$ 5.0, J(5,6) = 3.0 Hz, 1H, H-5, E), 5.37 (ddd, J(4,5) = 9.0, J(5,6') $=5.0, J(5,6)=3.0 \mathrm{~Hz}, 1 \mathrm{H}, \mathrm{H}-5, Z), 4.27\left(\mathrm{dd}, J\left(6,6^{\prime}\right)=12.5, J(5,6)\right.$ $=3.0 \mathrm{~Hz}, 1 \mathrm{H}, \mathrm{H}-6, E), 4.21\left(\mathrm{dd}, J\left(6,6^{\prime}\right)=12.0, J(5,6)=3.0 \mathrm{~Hz}\right.$, $1 \mathrm{H}, \mathrm{H}-6, \mathrm{Z}), 4.18\left(\mathrm{dd}, \mathrm{J}\left(6,6^{\prime}\right)=12.5, J\left(5,6^{\prime}\right)=5,0 \mathrm{~Hz}, 1 \mathrm{H}, \mathrm{H}-6^{\prime}\right.$, E), $4.11\left(\mathrm{dd}, J\left(6,6^{\prime}\right)=12.0, J\left(5,6^{\prime}\right)=5.0 \mathrm{~Hz}, 1 \mathrm{H}, \mathrm{H}-6^{\prime}, Z\right), 1.78(\mathrm{~s}$, $\left.3 \mathrm{H}, \mathrm{CH}_{3}, E\right), 1.70\left(\mathrm{~s}, 3 \mathrm{H}, \mathrm{CH}_{3}, E\right), 1.56\left(\mathrm{~s}, 3 \mathrm{H}, \mathrm{CH}_{3}, E\right) ;{ }^{13} \mathrm{C} \mathrm{NMR}$ $\left(125 \mathrm{MHz}, \mathrm{C}_{6} \mathrm{D}_{6}\right) \delta 169.9(E), 169.5(E), 169.4(E), 169.2(Z)$, $154.1(Z), 152.9(E), 150.5(E), 141.7(Z), 138.5(Z), 137.4(E)$, $131.5(E), 129.3(E), 129.2(Z), 127.3(Z), 123.5(Z), 123.3(E)$, $119.5(Z), 72.1(Z), 70.3(E), 70.2(Z), 70.1(Z), 69.6(Z), 69.5$ $(E), 68.7(E), 62.0(E), 61.9(Z) 20.4(E), 20.3(Z), 20.2(E), 20.1$ (E), $20.0(Z), 19.9(E)$.

Mixture of Compounds (1E,3E)-4-(tetra-O-acetyl-D-arabinotetritol-1-yl)-1-(4-methoxyphenyl)-1,2-diaza-1,3-butadiene (5a) and (1Z,3E)-4-(tetra-O-acetyl-D-arabino-tetritol-1-yl)-1(4-methoxyphenyl)-1,2-diaza-1,3-butadiene (5c): $E / Z$ ratio after equilibration $(\%)=94: 6 .{ }^{1} \mathrm{H}$ NMR $\left(500 \mathrm{MHz}, \mathrm{C}_{6} \mathrm{D}_{6}\right) \delta 7.89$ $(\mathrm{d}, J=9.0 \mathrm{~Hz}, 2 \mathrm{H}$, arom, $E), 7.65(\mathrm{dd}, J(1,2)=14.0, J(1,3)=1.0$ $\mathrm{Hz}, 1 \mathrm{H}, \mathrm{H}-1, E), 7.38(\mathrm{dd}, J(1,2)=13.5, J(1,3)=1.0 \mathrm{~Hz}, 1 \mathrm{H}, \mathrm{H}-1$, $Z), 6.87(\mathrm{dd}, J(1,2)=13.5, J(2,3)=6.5 \mathrm{~Hz}, 1 \mathrm{H}, \mathrm{H}-2, Z), 6.86(\mathrm{~m}$, $1 \mathrm{H}$, arom, Z), $6.84(\mathrm{dd}, J(1,2)=14.0, J(2,3)=6.0 \mathrm{~Hz}, 1 \mathrm{H}, \mathrm{H}-2$, $E), 6.66(\mathrm{~d}, J=9.0 \mathrm{~Hz}, 2 \mathrm{H}$, arom, E), $6.60(\mathrm{~m}, 1 \mathrm{H}$, arom, Z), 6.06 $($ ddd, $J(2,3)=6.0, J(3,4)=3.0, J(1,3)=1.5 \mathrm{~Hz}, 1 \mathrm{H}, \mathrm{H}-3, E), 5.79$ (ddd, $J(2,3)=6.5, J(3,4)=3.5, J(1,3)=1.0 \mathrm{~Hz}, 1 \mathrm{H}, \mathrm{H}-3, Z), 5.64$ $(\mathrm{dd}, J(4,5)=9.0, J(3,4)=3.0 \mathrm{~Hz}, 1 \mathrm{H}, \mathrm{H}-4, E), 5.56(\mathrm{dd}, J(4,5)=$ 8.5, J(3,4) = 3.5 Hz, 1H, H-4, Z), $5.47\left(\mathrm{ddd}, J(4,5)=9.0, J\left(5,6^{\prime}\right)=\right.$ 5.0, J(5,6) = 3.0 Hz, 1H, H-5, E), 5.41 (ddd, $J(4,5)=8.5, J\left(5,6^{\prime}\right)$ $=5.0, J(5,6)=2.5, \mathrm{~Hz}, 1 \mathrm{H}, \mathrm{H}-5, Z), 4.28\left(\mathrm{dd}, J\left(6,6^{\prime}\right)=12.5\right.$, $J(5,6)=3.0 \mathrm{~Hz}, 1 \mathrm{H}, \mathrm{H}-6, E), 4.24\left(\mathrm{dd}, J\left(6,6^{\prime}\right)=12.5, J(5,6)=3.0\right.$ $\mathrm{Hz}, 1 \mathrm{H}, \mathrm{H}-6, \mathrm{Z}), 4.19\left(\mathrm{dd}, J\left(6,6^{\prime}\right)=12.5, J\left(5,6^{\prime}\right)=5.0 \mathrm{~Hz}, 1 \mathrm{H}, \mathrm{H}-\right.$

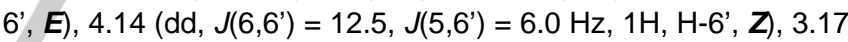
(s, 3H, $\mathrm{CH}_{3}, Z$ ), 3.10 (s, 3H, CH, E), 1.78 (s, 3H, CH $\left.\mathrm{CH}_{3}, E\right), 1.73$ (s, 3H, $\left.\mathrm{CH}_{3}, E\right), 1.72\left(\mathrm{~s}, 3 \mathrm{H}, \mathrm{CH}_{3}, Z\right), 1.71\left(\mathrm{~s}, 3 \mathrm{H}, \mathrm{CH}_{3}, E\right), 1.69$ (s, 3H, $\left.\mathrm{CH}_{3}, Z\right), 1.63\left(\mathrm{~s}, 3 \mathrm{H}, \mathrm{CH}_{3}, Z\right), 1.62\left(\mathrm{~s}, 3 \mathrm{H}, \mathrm{CH}_{3}, Z\right), 1.59$ (s, 3H, $\left.\mathrm{CH}_{3}, E\right) ;{ }^{13} \mathrm{C}$ NMR $\left(125 \mathrm{MHz}, \mathrm{C}_{6} \mathrm{D}_{6}\right) \delta 169.4(E), 169.5$ $(E), 169.4(E), 162.8(E) 150.8(E), 147.4(E), 142.5(Z), 135.9$ (Z), $135.0(E), 125.6(Z), 125.3(E), 122.7(Z), 114.6(Z), 114.5$ $(E), 114.2(Z), 70.4(E), 69.9(Z), 69.7(E), 68.8(E), 62.1(E)$, $61.9(Z), 55.0(E), 54.9(Z), 20.4(E), 20.3(Z), 20.2(E), 20.1(E)$, $19.9(E)$.

Mixture of Compounds (1E,3E)-4-(tetra-O-acetyl-D-arabinotetritol-1-yl)-1-(4-methylphenyl)-1,2-diaza-1,3-butadiene (6a) and (1Z,3E)-4-(tetra-O-acetyl-D-arabino-tetritol-1-yl)-1-(4methylphenyl)-1,2-diaza-1,3-butadiene (6c): $E / Z$ ratio after equilibration (\%) = 93:7. ${ }^{1} \mathrm{H}$ NMR $\left(500 \mathrm{MHz}, \mathrm{C}_{6} \mathrm{D}_{6}\right) \delta 7.83(\mathrm{~d}, \mathrm{~J}=$ $8.5 \mathrm{~Hz}, 2 \mathrm{H}$, arom, E), $7.63(\mathrm{dd}, J(1,2)=13.5, J(1,3)=1.5 \mathrm{~Hz}$, $1 \mathrm{H}, \mathrm{H}-1, E), 7.32(\mathrm{dd}, J(1,2)=13.5, J(1,3)=1.0 \mathrm{~Hz}, 1 \mathrm{H}, \mathrm{H}-1, Z)$, $6.91(\mathrm{~d}, \mathrm{~J}=8.5 \mathrm{~Hz}, 2 \mathrm{H}$, arom, E), $6.86(\mathrm{dd}, \mathrm{J}(1,2)=13.5, \mathrm{~J}(2,3)$ $=6.0 \mathrm{~Hz}, 1 \mathrm{H}, \mathrm{H}-2, E), 6.79(\mathrm{dd}, J(1,2)=13.5, J(2,3)=6.0 \mathrm{~Hz}$ $1 \mathrm{H}, \mathrm{H}-2, \mathrm{Z}), 6.05(\mathrm{ddd}, J(2,3)=5.5, J(3,4)=3.0, J(1,3)=1.5 \mathrm{~Hz}$, $1 \mathrm{H}, \mathrm{H}-3, E), 5.76(\mathrm{ddd}, J(2,3)=5.5, J(3,4)=3.0, J(1,3)=1.5 \mathrm{~Hz}$, $1 \mathrm{H}, \mathrm{H}-3, Z), 5.63(\mathrm{dd}, J(4,5)=9.0, J(3,4)=3.0,1 \mathrm{H}, \mathrm{H}-4, E), 5.52$ $(d d, J(4,5)=9.0, J(3,4)=3.0,1 \mathrm{H}, \mathrm{H}-4, Z), 5.47(\mathrm{ddd}, J(4,5)=$ $\left.9.0, J\left(5,6^{\prime}\right)=6.0, J(5,6)=3.0 \mathrm{~Hz}, 1 \mathrm{H}, \mathrm{H}-5, E\right), 5.39(\mathrm{ddd}, J(4,5)$ $\left.=9.0, J\left(5,6^{\prime}\right)=6.0, J(5,6)=3.0 \mathrm{~Hz}, 1 \mathrm{H}, \mathrm{H}-5, Z\right), 4.27\left(\mathrm{dd}, J\left(6,6^{\prime}\right)\right.$ 
$=12.5, J(5,6)=3.0 \mathrm{~Hz}, 1 \mathrm{H}, \mathrm{H}-6, E), 4.22\left(\mathrm{dd}, J\left(6,6^{\prime}\right)=12.5\right.$ $J(5,6)=3.0 \mathrm{~Hz}, 1 \mathrm{H}, \mathrm{H}-6, Z), 4.17\left(\mathrm{dd}, J\left(6,6^{\prime}\right)=12.5, J\left(5,6^{\prime}\right)=5.0\right.$ $\left.\mathrm{Hz}, 1 \mathrm{H}, \mathrm{H}-6^{\prime}, E\right), 4.12\left(\mathrm{dd}, J\left(6,6^{\prime}\right)=12.5, J\left(5,6^{\prime}\right)=5.0 \mathrm{~Hz}, 1 \mathrm{H}, \mathrm{H}-\right.$ 6', Z), 1.97 (s, 3H, $\left.\mathrm{CH}_{3}, E\right), 1.78\left(\mathrm{~s}, 3 \mathrm{H}, \mathrm{CH}_{3}, E\right), 1.71(\mathrm{~s}, 3 \mathrm{H}$, $\left.\mathrm{CH}_{3}, E\right), 1.70\left(\mathrm{~s}, 3 \mathrm{H}, \mathrm{CH}_{3}, E\right), 1.57\left(\mathrm{~s}, 3 \mathrm{H}, \mathrm{CH}_{3}, E\right) ;{ }^{13} \mathrm{C} \mathrm{NMR}$ $\left(125 \mathrm{MHz}, \mathrm{C}_{6} \mathrm{D}_{6}\right) \delta 169.9(E), 169.5(E), 169.4(E), 169.3(Z)$, $151.7(Z), 151.3(E), 150.7(E), 142.1(Z), 142.0(E), 137.5(Z)$, $137.4(Z), 136.4(E), 130.0(E), 129.7(Z), 123.4(Z), 120.1(Z)$, $70.3(E), 69.7(Z), 69.5(E), 68.7(E), 62.0(E), 61.9(Z), 21.2(E)$, 20.8 (Z), $20.4(E), 20.3(Z), 20.2(E), 20.1(E), 20.0(Z), 19.9(E)$.

Mixture of Compounds (1E,3E)-4-(tetra-O-acetyl-D-arabino tetritol-1-yl)-1-(4-chlorophenyl)-1,2-diaza-1,3-butadiene (7a) and (1Z,3E)-4-(tetra-O-acetyl-D-arabino-tetritol-1-yl)-1-(4chlorophenyl)-1,2-diaza-1,3-butadiene (7c): $E / Z$ ratio after equilibration (\%) = 91:9. ${ }^{1} \mathrm{H}$ NMR $\left(500 \mathrm{MHz}, \mathrm{C}_{6} \mathrm{D}_{6}\right) \delta 7.55(\mathrm{~d}, \mathrm{~J}=$ $6.5 \mathrm{~Hz}, 2 \mathrm{H}$, arom, E), $7.54(\mathrm{dd}, J(1,2)=13.5, J(1,3)=1.5 \mathrm{~Hz}$, $1 \mathrm{H}, \mathrm{H}-1, E), 7.11(\mathrm{dd}, J(1,2)=13.5, J(1,3)=1.0 \mathrm{~Hz}, 1 \mathrm{H}, \mathrm{H}-1, Z)$, $7.01(\mathrm{~d}, J=6.5 \mathrm{~Hz}, 2 \mathrm{H}$, arom, $E), 6.92(\mathrm{dd}, J(1,2)=13.5, J(1,3)$ $=6.5 \mathrm{~Hz}, 1 \mathrm{H}, \mathrm{H}-2, \mathrm{Z}), 6.90(\mathrm{~m}, 2 \mathrm{H}, \mathrm{Z}), 6.87(\mathrm{dd}, J(1,2)=13.5$, $J(1,3)=5.5 \mathrm{~Hz}, 1 \mathrm{H}, \mathrm{H}-2, E), 6.42(\mathrm{~m}, 2 \mathrm{H}$, arom, Z), 6.04 (ddd, $J(2,3)=5.5, J(3,4)=3.0, J(1,3)=1.5 \mathrm{~Hz}, 1 \mathrm{H}, \mathrm{H}-3, E), 5.75$ (ddd, $J(2,3)=6.5, J(3,4)=3.0, J(1,3)=1.0 \mathrm{~Hz}, 1 \mathrm{H}, \mathrm{H}-3, Z), 5.62(\mathrm{dd}$ $J(4,5)=9.0, J(3,4)=3,0,1 \mathrm{H}, \mathrm{H}-4, E), 5.51(\mathrm{dd}, J(4,5)=8.5$, $J(3,4)=3.0 \mathrm{~Hz} 1 \mathrm{H}, \mathrm{H}-4, Z), 5.45\left(\mathrm{ddd}, J(4,5)=8.5, J\left(5,6^{\prime}\right)=5.0\right.$, $J(5,6)=3.0 \mathrm{~Hz}, 1 \mathrm{H}, \mathrm{H}-5, E), 5.37\left(\mathrm{ddd}, J(4,5)=8.5, J\left(5,6^{\prime}\right)=\right.$ $5.0, J(5,6)=3.0 \mathrm{~Hz}, 1 \mathrm{H}, \mathrm{H}-5, Z), 4.26\left(\mathrm{dd}, J\left(6,6^{\prime}\right)=12.5, J(5,6)=\right.$ $3.0 \mathrm{~Hz}, 1 \mathrm{H}, \mathrm{H}-6, E), 4.21$ (dd, J(6,6') = 12.5, J(5,6) = 3.0 Hz, $1 \mathrm{H}$, $\mathrm{H}-6, Z) 4.17\left(\mathrm{dd}, J\left(6,6^{\prime}\right)=12.5, J\left(5,6^{\prime}\right)=5.0 \mathrm{~Hz}, 1 \mathrm{H}, \mathrm{H}-6^{\prime}, E\right)$, $4.12\left(\mathrm{dd}, J\left(6,6^{\prime}\right)=12.5, J\left(5,6^{\prime}\right)=5.0 \mathrm{~Hz}, 1 \mathrm{H}, \mathrm{H}-6^{\prime}, Z\right), 1.78(\mathrm{~s}$, $\left.3 \mathrm{H}, \mathrm{CH}_{3}, E\right), 1.71\left(\mathrm{~s}, 3 \mathrm{H}, \mathrm{CH}_{3}, E\right), 1.70\left(\mathrm{~s}, 3 \mathrm{H}, \mathrm{CH}_{3}, E\right), 1.58$ (s, $\left.3 \mathrm{H}, \mathrm{CH}_{3}, \boldsymbol{E}\right) ;{ }^{13} \mathrm{C}$ NMR $\left(125 \mathrm{MHz}, \mathrm{C}_{6} \mathrm{D}_{6}\right) \delta 169.6(\boldsymbol{E}), 169.1(\boldsymbol{E})$, $169.0(E), 150.9(E), 150.0(E), 141.3(Z), 138.8(Z), 137.6(E)$, $137.1(E), 129.2(E), 129.0(Z), 124.2(E), 120.8(Z), 70.0(E)$, $69.2(E), 68.4(E), 61.7(E), 61.5(Z), 20.1(E), 20.0(Z), 19.9(E)$, $19.8(E), 19.6(E)$.

Mixture of Compounds (1E,3E)-4-(tetra-O-acetyl-D-arabinotetritol-1-yl)-1-(4-bromophenyl)-1,2-diaza-1,3-butadiene (8a) and (1Z,3E)-4-(tetra-O-acetyl-D-arabino-tetritol-1-yl)-1-(4bromophenyl)-1,2-diaza-1,3-butadiene (8c): $E / Z$ ratio after equilibration $(\%)=91: 9 .{ }^{1} \mathrm{H} \mathrm{NMR}\left(500 \mathrm{MHz}, \mathrm{C}_{6} \mathrm{D}_{6}\right) \delta 7.54$ (dd, $J(1,2)=13.5, J(1,3)=1.5 \mathrm{~Hz}, 1 \mathrm{H}, \mathrm{H}-1, E), 7.48(\mathrm{~d}, J=8.5 \mathrm{~Hz}$, $2 \mathrm{H}$, arom, $E$ ), $7.18(\mathrm{~d}, \mathrm{~J}=8.5 \mathrm{~Hz}, 2 \mathrm{H}$, arom, $E$ ), 7.10 (dd, $\mathrm{J}(1,2)$ $=13.5, J(1,3)=1.5 \mathrm{~Hz}, 1 \mathrm{H}, \mathrm{H}-1, \mathrm{Z}), 7.05(\mathrm{~m}, 2 \mathrm{H}$, arom, Z), 6.91 $(d d, J(1,2)=13.5, J(2,3)=6.0 \mathrm{~Hz}, 1 \mathrm{H}, \mathrm{H}-2, Z), 6.87(\mathrm{dd}, J(1,2)=$ 13.5, J(2,3) $=5.5 \mathrm{~Hz}, 1 \mathrm{H}, \mathrm{H}-2, \mathrm{E}), 6.03(\mathrm{ddd}, J(2,3)=5.5, J(3,4)$ $=3.0, J(1,3)=1.5 \mathrm{~Hz}, 1 \mathrm{H}, \mathrm{H}-3, E), 5.75$ (ddd, $J(2,3)=6.0, J(3,4)$ $=3.0, J(1,3)=1.5 \mathrm{~Hz}, 1 \mathrm{H}, \mathrm{H}-3, Z), 5.62(\mathrm{dd}, J(4,5)=9.0, J(3,4)$ $=3.0 \mathrm{~Hz}, 1 \mathrm{H}, \mathrm{H}-4, E), 5.51(\mathrm{dd}, J(4,5)=8.5, J(3,4)=3.0,1 \mathrm{H}, \mathrm{H}-$ $4, Z), 5.46\left(d d d, J(4,5)=8.5, J\left(5,6^{\prime}\right)=5.0, J(5,6)=3.0 \mathrm{~Hz}, 1 \mathrm{H}\right.$, $\mathrm{H}-5, E), 5.36\left(\mathrm{ddd}, J(4,5)=8.5, J\left(5,6^{\prime}\right)=5.0, J(5,6)=3.0 \mathrm{~Hz}\right.$, $1 \mathrm{H}, \mathrm{H}-5, Z), 4.27\left(\mathrm{dd}, J\left(6,6^{\prime}\right)=12.5, J(5,6)=3.0 \mathrm{~Hz}, 1 \mathrm{H}, \mathrm{H}-6, E\right)$, $4.21\left(\mathrm{dd}, J\left(6,6^{\prime}\right)=12.5, J(5,6)=3.0 \mathrm{~Hz}, 1 \mathrm{H}, \mathrm{H}-6, Z\right), 4.17(\mathrm{dd}$, $\left.J\left(6,6^{\prime}\right)=12.5, J\left(5,6^{\prime}\right)=5.0 \mathrm{~Hz}, 1 \mathrm{H}, \mathrm{H}-6^{\prime}, E\right), 4.11\left(\mathrm{dd}, J\left(6,6^{\prime}\right)=\right.$ $\left.12.5, J\left(5,6^{\prime}\right)=5.0 \mathrm{~Hz}, 1 \mathrm{H}, \mathrm{H}-6^{\prime}, Z\right), 1.77\left(\mathrm{~s}, 3 \mathrm{H}, \mathrm{CH}_{3}, E\right), 1.71$ (s, $\left.3 \mathrm{H}, \mathrm{CH}_{3}, E\right), 1.70\left(\mathrm{~s}, 3 \mathrm{H}, \mathrm{CH}_{3}, E\right), 1.57\left(\mathrm{~s}, 3 \mathrm{H}, \mathrm{CH}_{3}, E\right), ;{ }^{13} \mathrm{C}$ $\operatorname{NMR}\left(125 \mathrm{MHz}, \mathrm{C}_{6} \mathrm{D}_{6}\right) \delta 169.8(E), 169.4(E), 169.3(E) 151.6$ $(E), 150.3(E), 141.6(Z), 139.2(Z), 138.0(E), 132.5(E), 132.3$ (Z), $126.0(Z), 124.7(E), 121.3(Z), 70.3(E), 69.5(Z), 69.5(E)$, $68.7(E), 62.0(E), 61.9(Z), 20.4(E), 20.2(E), 20.1(E), 19.9(E)$.
Mixture of Compounds (1E,3E)-4-(tetra-O-acetyl-D-lyxotetritol-1-yl)-1-phenyl-1,2-diaza-1,3-butadiene (9a) and (1Z,3E)-4-(tetra-O-acetyl-D-lyxo-tetritol-1-yl)-1-phenyl-1,2 diaza-1,3-butadiene (9c): $E / Z$ ratio after equilibration (\%) = 90:10. ${ }^{1} \mathrm{H}$ NMR $\left(500 \mathrm{MHz}, \mathrm{C}_{6} \mathrm{D}_{6}\right) \delta 7.83(\mathrm{~d}, J=8.5 \mathrm{~Hz}, 2 \mathrm{H}$, arom, E), $7.61(\mathrm{dd}, J(1,2)=13.5, J(1,3)=1.0 \mathrm{~Hz}, 1 \mathrm{H}, \mathrm{H}-1, E), 7.28(\mathrm{dd}$, $J(1,2)=13.5, J(1,3)=1.0 \mathrm{~Hz}, 1 \mathrm{H}, \mathrm{H}-1, \mathrm{Z}), 7.07(\mathrm{~m}, 2 \mathrm{H}$, arom, $E), 7.03(\mathrm{~d}, \mathrm{~J}=7.0 \mathrm{~Hz}, 1 \mathrm{H}$, arom, $E), 6.94(\mathrm{dd}, J(1,2)=13.5$, $J(1,2)=7.5 \mathrm{~Hz}, 1 \mathrm{H}, \mathrm{H}-2, E), 6.82(\mathrm{~m}, 1 \mathrm{H}$, arom, $Z), 6.69(\mathrm{~m}, 2 \mathrm{H}$, arom, Z), 5.94 (t, J = $7.5 \mathrm{~Hz}, 1 \mathrm{H}, \mathrm{H}-3, E), 5.64$ (ddd, J(5,6') = $7.0, J(5,6)=5.5, J(4,5)=3.0 \mathrm{~Hz}, 1 \mathrm{H}, \mathrm{H}-5, E), 5.60(\mathrm{dd}, J(3,4)=$ $7.5, J(4,5)=3.0 \mathrm{~Hz}, 1 \mathrm{H}, \mathrm{H}-4, E), 5.52$ (ddd, J(5,6') = 7.0, J(5,6) $=5.5, J(4,5)=3.0 \mathrm{~Hz}, 1 \mathrm{H}, \mathrm{H}-5, Z), 5.48(\mathrm{dd}, J(3,4)=7.5, J(4,5)$ $=3.0 \mathrm{~Hz}, 1 \mathrm{H}, \mathrm{H}-4, Z), 4.33\left(\mathrm{dd}, J\left(6,6^{\prime}\right)=11.5, J(5,6)=5.5 \mathrm{~Hz}\right.$, $1 \mathrm{H}, \mathrm{H}-6, E), 4.28\left(\mathrm{dd}, J\left(6,6^{\prime}\right)=11.5, J(5,6)=5.5 \mathrm{~Hz}, 1 \mathrm{H}, \mathrm{H}-6, Z\right)$, $3.98\left(\mathrm{dd}, J\left(6,6^{\prime}\right)=11.5, \mathrm{~J}\left(5,6^{\prime}\right)=7.0 \mathrm{~Hz}, 1 \mathrm{H}, \mathrm{H}-6^{\prime}, E\right), 3.90(\mathrm{dd}$, $\left.J\left(6,6^{\prime}\right)=11.5, J\left(5,6^{\prime}\right)=7.0 \mathrm{~Hz}, 1 \mathrm{H}, \mathrm{H}-6^{\prime}, \mathrm{Z}\right), 1.74\left(\mathrm{~s}, 3 \mathrm{H}, \mathrm{CH}_{3}, E\right)$, $1.68\left(\mathrm{~s}, 3 \mathrm{H}, \mathrm{CH}_{3}, E\right), 1.67\left(\mathrm{~s}, 3 \mathrm{H}, \mathrm{CH}_{3}, E\right), 1.56\left(\mathrm{~s}, 3 \mathrm{H}, \mathrm{CH}_{3}, E\right)$,; ${ }^{13} \mathrm{C}$ NMR $\left(125 \mathrm{MHz}, \mathrm{C}_{6} \mathrm{D}_{6}\right) \delta 169.8(E), 169.7(E), 169.4(E)$, $169.1(E), 153.0(E), 151.7(E), 142.6(Z), 138.1(Z), 136.8(E)$, $131.6(E), 129.3(E), 126.3(Z), 123.6(Z), 123.3(E), 119.4(Z)$, $106.9(Z), 71.2(E), 70.9(Z), 69.2(E), 69.0(Z), 68.5(E), 62.0$ $(E), 20.3(E), 20.2(E), 20.1(Z), 19.9(E)$.

\section{Acknowledgments}

Financial support from the Junta de Extremadura and Fondo Europeo de Desarrollo Regional (Grant GR18015 and Project IB16167) are greatly appreciated. The authors thank both Cenits and Foundation COMPUTAEX for allowing us the use of supercomputer LUSITANIA.

\section{Conflicts of interest}

The authors declare no conflict of interest.

Keywords: azoalkene · carbohydrates · chirality photoswitching $\cdot$ thermal isomerization

[1] a) S. Erbas-Cakmak, D. A. Leigh, C. T. McTernan, A. L. Nussbaumer, Chem. Rev. 2015, 115, 10081-10206. b) J. D. Harris, M. J. Moran, I. Aprahamian, Proc. Natl. Acad. Sci. USA 2018, 115, 9414-9422.

[2] a) W.-C. Xu S. Sun, S. Wu, Angew. Chem. Int. Ed. 2019, 58, 9712-9740; Angew. Chem. 2019, 131, 9814-9843. b) A. H. Heindl, J. Becker, H. A. Wegner, Chem. Sci. 2019, 10, 7418-7425.

[3] For recent examples: a) A. Chevalier, P. Y. Renard, A. Romieu, Chem. Asian J. 2017, 12, 2008-2028. b) M. Dong, A. Babalhavaeji, C. V. Collins, K Jarrah, O. Sadovski, Q. Dai, G. A. Woolley, J. Am. Chem. Soc. 2017, 139 13483-13486. c) C.-Y. Lai, G. Raj, I. Liepuoniute, M. Chiesa, P. Naumov, Cryst. Growth Des. 2017, 17, 3306-3312. d) A. Adam, G. Haberhauer, J. Am Chem. Soc. 2017, 139, 9708-9713. e) P. S. Addy, S. B. Erickson, J. S. Italia, A. Chatterjee, J. Am. Chem. Soc. 2017, 139, 11670-11673. f) Y. Ma, K. Promthaveepong, N. Li, ACS Sensors 2017, 2, 135-139. g) M. Poutanen, Z. Ahmed, L. Rautkari, O. Ikkala, A. Priimagi, ACS Macro Lett. 2018, 7, 381-386 h) W.-C. Lin, R. H. Kramer, Bioconjugate Chem. 2018, 29, 861-869. i) T. Lutz, T. Wein, G. Höfner, J. Pabel, M. Eder, J. Dine, K. T. Wanner, J. Med. Chem. 2018, 61, 6211-6235.

[4] R. Dorel, B. L. Feringa, Chem. Commun. 2019, 55, 6477-6486. 
[5] L.-W. Qi, J.-H. Mao, J. Zhang, B. Tan, Nat. Chem. 2018, 10, 58-64.

[6] J. Morstein, M. Awale, J.-L. Reymond, D. Trauner, ACS Cent. Sci. 2019, 5, 607-618.

[7] a) M. L. Wolfrom, M. Blair, J. Am. Chem. Soc. 1946, 68, 2110-2111. b) L. Mester, A. Major, J. Am. Chem. Soc. 1955, 77, 4297-4300. c) L. Mester, H. El Khadem in The Carbohydrates: Chemistry and Biochemistry, Vol. IB (Eds.: W. Pigman, D. Horton), Academic Press, San Diego, 1980, pp. 929-988, and references therein.

[8] a) M. C. Wolfrom, A. Thompson, D. R. Linebak, J. Org. Chem. 1962, 27, 2563-2567. b) M. C. Wolfrom, G. Fraenkel, D. R. Linebak, F. Komitsky, J. Org. Chem. 1964, 29, 457-461.

[9] a) P. M. Collins, S. Kumar, W. G. Overend, Carbohydr. Res. 1972, 22, 187192. b) A. Kraus, H. Simon, Chem. Ber. 1972, 105, 954-968. c) V. Zsoldos, A. Messmer, I. Pintér, A. Neszmèlyi, Carbohydr. Res. 1978, 62, 105-116. d) L. Somogyi, Carbohydr. Res. 1988, 175, 183-192. e) O. Han, Y. Shih, L. Lin, H. Lin, J. Org. Chem. 1988, 53, 2105-2108. f) H. S. El Khadem Jr., A. Crossman, Carbohydr. Res. 1992, 228, 451-454. g) V. Zsoldos-Mády, I. Pintér, M. Peredy-Kajtár, A. Perczel, Carbohydr. Res. 2011, 346, 1534-1540.

[10] a) M. Ávalos, R. Babiano, P. Cintas, J. L. Jiménez, J. C. Palacios, J. B. Sánchez, Tetrahedron: Asymmetry 1995, 6, 945-956. b) The original numbering of starting sugars D-mannose and D-galactose is maintained in the resulting azadienes to clarify the discussion and comparative analysis through the text. The correct nomenclature is given in the Experimental section.

[11] E. Merino, M. Ribagorda, Beilstein J. Org. Chem. 2012, 8, 1071-1090.

[12] a) O. Srinivas, N. Mitra, A. Surolia, N. Jayaraman, Glycobiology 2005, 15, 861-873. B) For a perspective: F. Hamon, F. Djedaini-Pilard, F. Barbot, C. Len, Tetrahedron 2009, 65, 10105-10123. c) For a recent example on a glycomacrocycle: J. Hain, G. Despras, Chem. Commun. 2018, 54, 8563-8566. [13] a) Y. Ogawa, C. Yoshiyama, T. Kitaoka, Langmuir 2012, 28, 4404-4412. b) R. F. Tabor, D. D. Tan, S. S. Han, S. A. Young, Z. L. E. Seeger, M. J. Pottage, C. J. Garvey, B. L. Wilkinson, Chem. Eur. J. 2014, 20, 13881-13884. c) F. Reise, J E. Warias, K. Chatterjee, N. R. Krekiehn, O. Magnussen, B. M. Murphy, T. K. Lindhorst, Chem. Eur. J. 2018, 24, 17497-17505.

[14] D. R. Armstrong, J. Clarkson, W. E. Smith, J. Phys. Chem. 1995, 99, 17825-17831.

[15] a) J. G. Schantl, Org. Magn. Reson. 1979, 12, 652-654. b) J. G. Schantl, P. Margaretha, Helv. Chim. Acta 1981, 64, 2492-2494.

[16] J. G. Schantl, P. Hebeisen, Tetrahedron 1990, 46, 395-406.

[17] Crystal data for compound $\mathbf{5 a}$ have been deposited with the Cambridge Crystallographic Data Centre (CCDC-1828935).

[18] Crystal data for compound $\mathbf{6 a}^{[10]}$ have been reported in a separate study: M. J. Diánez, M. D. Estrada, S. Pérez-Garrido, Acta Cryst. 2006, E62, 28112812.

[19] C. Jørgensen, C. Pedersen, Carbohydr. Res. 1997, 299, 307-310.

[20] Y. Zhao, D. G. Truhlar, Theor. Chem. Acc. 2008, 120, 215-241.

[21] a) A. D. McLean, G. S. Chandler, J. Chem. Phys. 1980, 72, 5639-5648. b) K. Raghavachari, J. S. Binkley, R. Seeger, J. A. Pople, J. Chem. Phys. 1980 , 72, 650-654.

[22] M. J. Frisch, G. W. Trucks, H. B. Schlegel, G. E. Scuseria, M. A. Robb, J. R. Cheeseman, G. Scalmani, V. Barone, B. Mennucci, G. A. Petersson, H. Nakatsuji, M. Caricato, X. Li, H. P. Hratchian, A. F. Izmaylov, J. Bloino, G. Zheng, J. L. Sonnenberg, M. Hada, M. Ehara, K. Toyota, R. Fukuda, J. Hasegawa, M. Ishida, T. Nakajima, Y. Honda, O. Kitao, H. Nakai, T. Vreven, J. A. Montgomery Jr, J. E. Peralta, F. Ogliaro, M. Bearpark, J. J. Heyd, E. Brothers, K. N. Kudin, V. N. Staroverov, R. Kobayashi, J. Normand, K. Raghavachari, A. Rendell, J. C. Burant, S. S. Iyengar, J. Tomasi, M. Cossi, N. Rega, J. M. Millam, M. Klene, J. E. Knox, J. B. Cross, V. Bakken, C. Adamo, J.
Jaramillo, R. Gomperts, R. E. Stratmann, O. Yazyev, A. J. Austin, R. Cammi, C. Pomelli, J. W. Ochterski, R. L. Martin, K. Morokuma, V. G. Zakrzewski, G. A. Voth, P. Salvador, J. J. Dannenberg, S. Dapprich, A. D. Daniels, Ö. Farkas, J. B. Foresman, J. V. Ortiz, J. Cioslowski, D. J. Fox, Gaussian 09, Revision A.1, Gaussian Inc., Wallingford, CT, 2009.

[23] A. V. Marenich, C. J. Cramer, D. G. Truhlar, J. Phys. Chem. B 2009, 113, 6378-6396.

[24] P. Deslongchamps, Stereoelectronic Effects in Organic Chemistry, Pergamon Press, New York, 1985.

[25] For some reviews on azadienes: a) O. A. Attanasi, L. Caglioti, Org. Prep. Proced. Int. 1986, 18, 301-327. b) O. A. Attanasi, P. Filippone, Synlett 1997, 1128-1140. c) O. A. Attanasi, L. De Crescentini, G. Favi, P. Filippone, F. Mantellini, F. R. Perrulli, S. Santeusanio, Eur. J. Org. Chem. 2009, 3109-3127. d) A. Lemos, Molecules 2009, 14, 4098-4119.

[26] For cycloadditive chemistry using chiral azoalkenes derived from monosaccharides: a) M. Ávalos, R. Babiano, P. Cintas, F. R. Clemente, J. L. Jiménez, J. C. Palacios, J. B. Sánchez, J. Org. Chem. 1999, 64, 6297-6305. b) M. Ávalos, R. Babiano, P. Cintas, F. R. Clemente, R. Gordillo, J. L. Jiménez, J. C. Palacios, P. Raithby, J. Org. Chem. 2000, 65, 5089-5097. c) M. Ávalos, R. Babiano, P. Cintas, F. R. Clemente, R. Gordillo, J. L. Jiménez, J. C Palacios, J. Org. Chem. 2001, 66, 5139-5145. d) M. Ávalos, R. Babiano, P. Cintas, F. R. Clemente, R. Gordillo, J. L. Jiménez, J. C. Palacios, J. Org. Chem. 2002, 67, 2241-2251.

[27] G. A. Doorakian, H. H. Freedman, J. Am. Chem. Soc. 1968, 90, 53105311.

[28] C. Reichardt, Solvents and Solvent Effects in Organic Chemistry, $3^{\text {rd }}$ Ed., Wiley-VCH, Weinheim, 2003, pp. 197-198.

[29] a) D. S. Malament, N. Levi, J. Org. Chem. 1975, 40, 3285-3287. b) A. A. Reid, H. R. Sood, J. T. Sharp, J. Chem. Soc. Perkin Trans 1 1976, 362-366. c) H. McNab, E. A. Murray, J. Chem. Soc. Perkin Trans 1 1981, 122-123. d) U. Ziegler, G. Zimmermann, B. Ondruschka, V. V. Volkova, L. E. Gusel'nikov, V. I. Smirnov, N. S. Nametkin, Tetrahedron Lett. 1986, 27, 5825-5828.

[30] N. P. Belskaia, T. G. Deryabina, A. V. Koksharov, M. I. Kodess, W Dehaen, A. T. Lebedev, V. A. Bakulev, Tetrahedron Lett. 2007, 48, 9128-9131. [31] R. C. Fahey, H. J. Schneider, J. Am. Chem. Soc. 1970, 92, 6885-6893.

[32] R. F. Childs, B. D. Dickie, J. Am. Chem. Soc. 1983, 105, 5041-5046.

[33] F. G. Bordwell, D. Algrim, J. Org. Chem. 1976, 41, 2507-2508.

[34] J. F. J. Dippy, S. R. C. Hughes, A. Rozanski, J. Chem. Soc. 1959, 2492 2498.

[35] F. G. Bordwell, Acc. Chem. Res. 1988, 21, 456-463.

[36] I. M. Kolthoff, P. J. Elving, Treatise on Analytical Chemistry, Interscience Encyclopedia, Inc., New York, 1959.

[37] C. Dugave, L. Demange, Chem. Rev. 2003, 103, 2475-2532.

[38] Y. Zhao, D. G. Truhlar, Acc. Chem. Res. 2008, 41, 157-167.

[39] A. V. Marenich, C. J. Cramer, D. J. Truhlar, J. Phys. Chem. B 2009, 113, 4538-4543. 


\section{Entry for the Table of Contents}

Insert graphic for Table of Contents here.
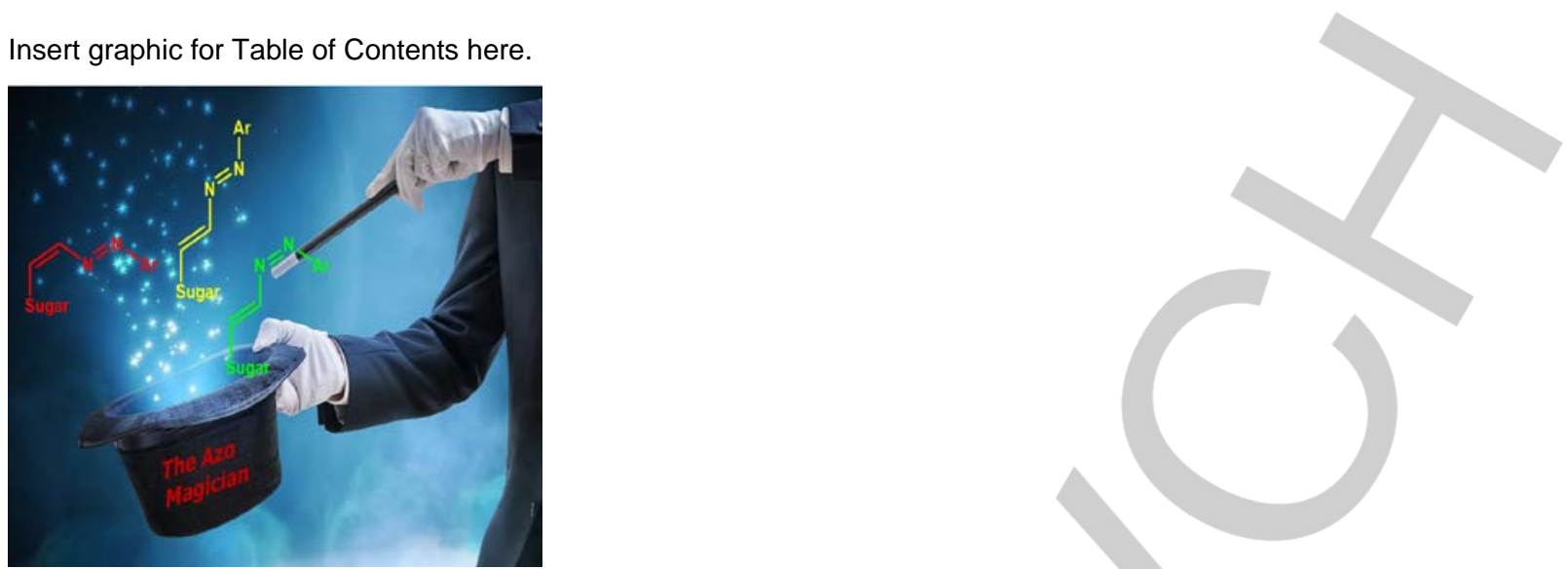

Magic Azo: Incorporation of the photolabile azo group into an unsaturated sugar chain affords a class of glycomimetics susceptible of thermal and photo-induced switches under mild conditions (sunlight irradiation). Here such stereomutations and mechanistic routes are disentangled by experiment and DFT calculations. 